Año LI. urtea

$127-2019$

Urtarrila-ekaina

Enero-junio

Sor

sens

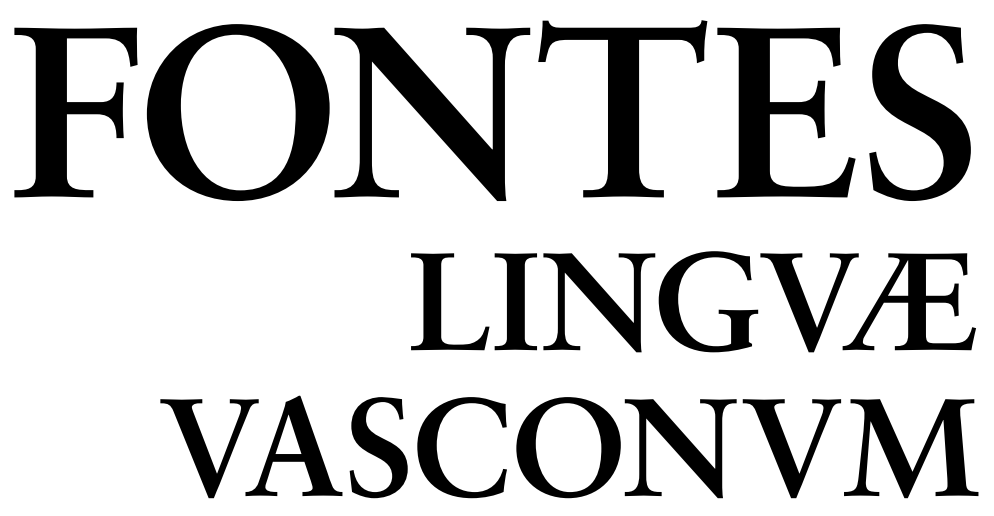

STVDIA ET DOCVMENTA

SEPARATA

Garaziko

hizkuntza-aldakortasuna geografiaren, adinaren eta generoaren arabera

Alexander Artzelus Muxika

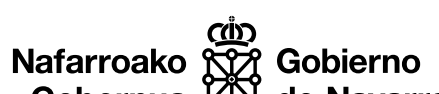

Gobernua \&S de Navarra

0000 


\section{Garaziko \\ hizkuntza-aldakortasuna geografiaren, adinaren eta generoaren arabera}

Variación en el dialecto vasco del valle de Cisa según geografía, edad y género

Variation of the Basque dialect from Garazi Valley according to geography, age and gender

Alexander ARTZELUS MUXIKA

Euskal Herriko Unibertsitatea (UPV/EHU)

Alex_aitza@hotmail.com 


\section{LABURPENA}

Nafarroa Behereko hegoaldean kokatuta dagoen, eta Nafarroa Garaiko Luzaide herria barne duen Garazi ibarreko euskararen aldakortasuna ikertzea da lan honen helburua. Hipotesi orokorra da bertako mintzoa abiada bizian aldatzen ari dela, eta hipotesi zehatzak dira berriz, aldaketa hori geografiaren, adinaren eta generoaren arabera gertatzen ari dela. Geografia aldagaiari dagokionez, Luzaide gainerako herrietatik aparte gelditzen ari dela uste dugu, muga politikoa hizkuntza-muga ere bihurtuz doala. Adinari dagokionez, berriz, adinekoak adinekoak gertuago daude base dialect deitzen den horretatik eta gazteek euskara batuaren eta frantsesaren edo gaztelaniaren eragin handiagoa dute. Azkenik, generoaren arabera, adineko emakumeak, gizonekin konparatuta, gordetzaile eta gazteak berritzaile dira.

Gako hitzak: soziolinguistika; aldakortasuna; Garazi.

\section{RESUMEN}

El propósito de este trabajo es analizar la variación del habla del valle de Cisa, situado al sur de la Baja Navarra, comprendiendo también el pueblo alto-navarro de Valcarlos. La hipótesis general es que el euskara de este valle está cambiando a un ritmo acelerado, y las hipótesis concretas son que la geografía, la edad y el género influyen en este cambio. En cuanto a la geografía, creemos que Valcarlos se está quedando aparte lingüísticamente de los demás pueblos, convirtiéndose así la frontera política en frontera lingüística. En cuanto a la edad, los mayores están más cerca de lo que se denomina base dialect y los jóvenes tienen más influencias del euskara estándar y del francés o español. Por último, en cuanto al género, las mujeres mayores son más conservadoras y las jóvenes más innovadoras que los hombres.

Palabras clave: sociolingüística; variación; Cisa.

\section{ABSTRACT}

The aim of this article is to analyze the variation of the Garazi valley, situated on the south of Lowern Navarre and the Upper Navarre town of Luzaide. The general hypothesis is that the Basque of this valley is changing fast, and the specific hypotheses are that this change is being led by geography, age and gender. Regarding geography, the Basque variety from Luzaide is becoming different from the rest of the villages due to the political frontier. In terms of age, oldest people are closer to the base dialect, and youngest people have more influences of standard Basque and French or Spanish. Finally, regarding gender, older women are more conservative and younger more innovative than men.

Keywords: sociolinguistics; variation; Garazi Valley. 
1. SARrera. 2. MARKo TEORIKOA. 2.1. Aldakortasunaz. 2.2. Hizkuntz aldaketa. 2.3. Aldagaia eta aldaera. 2.4. Hizkuntza aldagaiak edo menpeko aldagaiak. 2.4.1. Hasperena. 2.4.2. Dardarkari anizkuna. 2.4.3. [u] $\rightarrow<\mathrm{i}>/$ _[a, e] arau aldagarria. 2.4.4. Goranzko diptongoak. 2.4.5. (t) eta (d) aldagaiak. 2.5. Aldagai sozialak edo aldagai askeak. 2.5.1. Adina. 2.5.2. Generoa. 2.5.3. Aldagai geografikoa. 2.5.4. Ikasketamaila, ama-hizkuntza eta hezkuntza eredua. 2.6. Garazi ibarra. 3. IKERKETA HIPOTESIAK. 4. Metodologia. 4.1. Datuak bildu. 4.2. Datuak prozesatu. 4.3. Datuak aztertu. 5. DATUEN AZTERKETA. 5.1. Hasperena hitz hasieran. 5.2. Hasperena bokal artean. 5.3. Herskari hasperendunak. 5.4. Dardarkariak. 5.5. (1) araua $([\mathrm{u}] \rightarrow<\mathrm{i}>/$ _[a, e]). 5.6. Goranzko diptongoak: (2) araua ([i] $\rightarrow<j>/$ _ $[\mathrm{a}, \mathrm{e}, \mathrm{o}, \mathrm{u}]) .5 .7$. Goranzko diptongoak: (3) araua $([\mathrm{u}] \rightarrow<\mathrm{w}>/$ _ $[\mathrm{a}, \mathrm{e}, \mathrm{i}, \mathrm{o}]) .5 .8$. Goranzko diptongoak: (4) araua $\left([\mathrm{e}] \rightarrow<\mathrm{i}, \mathrm{e}, \mathrm{j}>/\right.$ _[a]). 5.9. Goranzko diptongoak: (5) araua $\left([\mathrm{o}] \rightarrow<\mathrm{o}, \mathrm{u}, \mathrm{w}>\right.$ / _ $\left._{\mathrm{a}}\right]$ ). 5.10. $(\mathrm{t})$ aldagaia. 5.11. (d) aldagaia. 5.12. Informatzaileen sailkapen orokorra. 6. ONDORIOAK. 7. ERREFERENTZIAK.

\section{SARRERA}

Gurean poliki-poliki garatzen dabilen soziolinguistika bariazionistaren beste ale bat gehiago izan nahi luke lan honek. Orain arte, hegoaldean egin izan dira era honetako lanak, baina Luzaiden Santaziliak (2009) egin zuenetik abiatuz, muga igaro eta Garazi ibar osoko aldakortasuna ikertu nahi genuke, euskararen aldakortasunaren ikerketa Iparraldean ere garatuz.

Garai bateko eta gaur egungo egoera soziolinguistikoa erabat desberdina da Garazi ibarrean. Euskararen beherakada ikaragarria izan da urte gutxian, eta gaur egun, badirudi badatorrela halako susperraldi bat. Jendeen mugikortasuna ere erabat aldatu da, garai batean, gehienez ere, Donibane Garazira gerturatzetik, Baiona, Iruñea, edota areago, Paris, Bordele eta Tolosara aise joaten baitira oraingo gazteak. Luzaide eta Garaziko gainerako herrien arteko harremana ere, ia erabat eten delakoan gaude, muga politikoa, muga sozial eta linguistiko bilakatzen ari baita. Ekonomia alorrean ere badira aldaketak, artzaintzatik eta abeltzaintzatik bizi izan den gizartea, gero eta gehiago baitago turismoari edota zerbitzuei so. Emakumearen errola ere, nola ez, izugarri aldatu da garai batetik hona.

Hau guztia kontuan hartuz, gure hipotesia da Garazi ibarreko euskara geografiaren, adinaren eta generoaren arabera aldatzen ari dela. Hipotesi hori frogatzeko, bistan dena, adina eta generoaren aldagai sozialak hartu ditugu kontuan gure azterketan, baita geografia ere.

Aukeratu ditugun hizkuntz aldagaiak berriz, fonetika-fonologiaren barrukoak izan dira guztiak. Hamaika aztertu ditugu, bost multzotan laburbildu ditugunak: 
hasperena, dardarkariak, [u] $\rightarrow<\mathrm{i}>/$ _[a, e] arau aldagarria, goranzko diptongoak eta $(\mathrm{t})$ eta $(\mathrm{d})$ aldagaiak.

Lehenik eta behin, marko teorikoan, oinarritu garen ikuspuntu teorikoa azalduko dugu eta jarraian, gure hipotesiak azalduko ditugu. Metodologian, datuak nola bildu, prozesatu eta aztertu ditugun azalduko dugu. Datuen azterketa etorriko da ondotik, aukeratutako hizkuntza ezaugarriak aldagai sozial eta geografikoaren arabera nola aldatzen diren ikusteko, eta azkenik, ondorioak aterako ditugu.

\section{MARKO TEORIKOA}

Marko teorikoan, beraz, edan dugun iturri teorikoei buruzko azalpenak emango ditugu. Aldakortasunaz egin denari buruzko behako bat ematetik hasi, hizkuntz aldaketarekin jarraitu, hizkuntz aldagai eta aldagai sozialak azaldu, eta azkenik, Garazi ibarrari buruzko argigarri batzuk emango ditut.

\subsection{Aldakortasunaz}

XX. mendearen erditsura arte, hizkuntza ikuspuntu erabat linguistiko eta immanentetik begiratuta aztertzen zen, hots, hizkuntza bere horretan aztertu beharra zegoen, kanpoko bestelako faktoreak, tartean soziala, kontuan hartu gabe.

Ikuspuntu hori, Labov-en ekarpenarekin batera, XX. mendearen bigarren erdian uzkaili zela esan liteke. Aldakortasuna librea ez dela eta hizkuntzaren baitako ezaugarria dela aldarrikatu zuen Labov-ek, baita aldakortasun hori sistematikoki azter daitekeela ere (Labov, 1969, 718. orr.). Erran liteke, bere lan egiteko era, oinarri teorikoak eta berak erabili zituen teknikak bizkor onetsi zirela 60ko hamarkadatik goiti (Camino, 2009c, 255. orr.).

Gurean, egiazko lan bariazionistak aurkitzeko, nahiko berandura arte itxaron behar izan dugu. Hor dugu, esaterako, 1985ean Maitena Etxebarriak kaleratu zuen Sociolingüistica urbana, el habla de Bilbao lana. Aurrerago, 2000. urtean, hiri bereko gaztelaniazko aldakortasun fonologikoa eta sintaktikoa ikertu zituen.

Garai berriagoetara etorrita, euskararen inguruko lan bariazionista garrantzitsuak hasi ziren ateratzen, esaterako Euskararen Atlas Sozio-Geolinguistikoa EAS proiektua hor dugu (Aurrekoetxea \& Ormaetxea, 2006). EUDIA ikerketa taldea ez da aipatu gabe uzten ahal, bertako ikertzaileek lan eskerga utzi baitigute euskararen aldakortasunari buruz, batez ere adina aldagaia kontuan hartuta. Hor ditugu, esaterako, Aurrekoetxeak (2004, 2006, 2008) egin zituen lanak, tartean Dimako aldakortasuna aztertuz, Ormaetxeak (2008) Otxandion, Perezek Beran (2006), Unamunok (2010) Gizaburuagan, Ariztimuñok (2010) Tolosan eta Ataunen, Ensunzak Gernika-Lumon $(2012,2014)$ eta Busturialdean (2015), Gandariasek (2012) azentu bariazioaz, Kortezubi, Lekaroz eta Tolosan egina, Gamindek (2010) Bilboko gazteen mintzoaz egin zuen lana, Gaminde eta Romerok (2011) eta hauekin batera Legarrak (2012) Bermeon egina, eta aztergai dugun eremu geografikora etorrita, Santaziliak (2009) Luzaiden egin zuena. 
Aipatu berri ditugun horiez gainera, Haddican-ek (2003, 2005, 2007) Oiartzunen egindako lanak ere baditugu, Lujanbiok Goizuetan $(2012,2014)$ eta Goizueta eta Araitz-Betelun eginak (2016), eta Iparraldeko euskararen aldakortasunaz egindako Norantz proiektua ere ezin liteke ahaztu (Oyharçabal, 2009).

\subsection{Hizkuntz aldaketa}

Hizkuntzek, bizirik badaude, aldaketak jasaten dituzte denboran zehar. Hauek arlo fonikoan, morfosintaktikoan eta lexikoan gertatzen dira. Talde sozialek eragiten dituzte, sistematikoak dira, eta beraz, hauen azterketa kuantitatiboa egin daiteke (Labov, 1963, 1969), azterketa kualitatiboaz gain.

Ez da erraza aldaketa linguistikoak nola hasten eta hedatzen diren jakitea, eta galdera horri emandako erantzunak ere ugari izan dira. Labov-en ustez (1972, 178 181. orr.), aldaketak behetik gorakoak edo goitik beherakoak izan daitezke. Lehen motakoen kasuan, aldaketak identitate berezia duen hiztun komunitatearen barruko talde sozial jakin batean espontaneoki sortzen eta hedatzen dira. Hiztunak ez dira aldaketa horren kontziente hasierako fasean, bederen. Motibazio linguistikoa dute, baina motibazio soziala ere izan dezakete. Goitik beherakoen kasuan ordea, aldaketa hizkuntza komunitatearen kanpoaldetik inportatua da, hiztunak aldaketa gertatzeaz kontziente dira, eta motibazioa soziala da (Tagliamonte, 2012, 58. orr.).

Hiru aldaketa mota bereiz ditzakegu: diatopikoa edo geografiaren araberako aldaketa, diastratikoa edo faktore sozialen araberako aldaketa (lan honetan aztertu duguna), eta azkenik diafasikoa edo estiloaren araberako aldaketa. Lehenengoa dialektologiak aztertzen du, eta azken biak berriz soziolinguistikak eta estilistikak. Hala ere, ukaezina da bi diziplinok duten harreman estua. Gainera, badira aldaketa diatopiko nahiz diastratikoa ikertu duten lanak gurean, esaterako, Ensunzak Busturialdeko euskararen aldakortasunaz egina (2015).

Dialektologiak, beraz, aldakortasun geografikoa ikertzen du, herri bateko mintzotik beste batekora dagoen aldea, ezaugarri bat aldatzen delarik, bi mintzoen artean isoglosa bat dagoela erranez. Aldakortasun geografikoa aztertzean, ordea, hizkera jakin bat duen hiztun-komunitate osoa berdin mintzatuko balitz bezala hartu izan da usu, komunitate horren barruan egon litekeen faktore sozial eta linguistikoen araberako aldakortasuna kontuan hartu gabe.

\subsection{Aldagaia eta aldaera}

Zarraga et al.-en arabera (2010, 94. orr.), aldagaia emaitza desberdinak eman ditzakeen balioa da eta aldakia berriz, aldagaiak izaten dituen emaitzetako bakoitza. Euskararen inguruan egin diren lan bariazionistetan, aldakia beharrean, aldaera terminoa izan da erabiliena, eta beraz, azken honen alde egingo dugu guk ere. Aldaerek ber balio erreferentziala dute, baina oso desberdinak izan daitezke euren esanahi sozial edo espresiboaren arabera. 


\subsection{Hizkuntza aldagaiak edo menpeko aldagaiak}

Honako menpeko hizkuntz aldagaiak ditugu: fonetiko-fonologikoak, morfologikoak, sintaktikoak eta lexikoak. Gure lanean lehen sailekoei baino ez diegu eskaini arreta. Bariazio fonetiko-fonologikoa izan da soziolinguistikan aztertuena izan denetarik bat, eta baita arazo teoriko gutxien izan duenetarik ere, besteak beste, fonema baten alofono bat edo beste erabiltzeak ez baitu esanahi linguistikoan aldaketarik ekartzen. Gainera, aldagai fonetiko-fonologikoak talde sozialen arabera ardura aldatu ohi dira, eta agerpen maiztasun handia ere badute (Labov, 1966, 6. orr.). Hauek dira gure lanean aztertuko ditugunak:

\subsubsection{Hasperena}

Iparraldean, eta Zugarramurdi, Kintoa edota Luzaide bezalako mugako leku batzuetan gaur egunera arte ahoskatu den fonema hau atzerabidean doa, besteak beste Jauregi eta Epeldek (2013) ondorioztatu duten bezala. Garaziko egoera aztertu nahirik, honako testuinguruok bereiziko ditugu gure lanean: hitz hasiera, bokal artea, eta herskari hasperendunak.

\subsubsection{Dardarkari anizkuna}

Mitxelenak (1990 [1977], 328. orr.) bere garaian grasseyement frantsesa delakoa gertatzen zebilela aipatu zuen Lapurdi eta Nafarroa Behereko euskaran, hots, dardarkari anizkuna ubular izaten hasia zela. Gaminde, Etxebarria, Eguskiza, Romero eta Iglesiasek erranari jarraituz (2017, 29. orr.), Euskararen Herri Hizkeren Atlaseko (aurrerantzean EHHA) «zorri» hitzari dagozkion emaitzak aztertuta, 32 hiztunek (\% 71,11) apikaria erabili zuten eta 13-k (\% 28,89) ubularra (1987-1992 bitartean egin ziren inkestak). Epelderi bagagozkio berriz (2014), badirudi berak ehun heldurekin egindako inkestan bik baino ez zutela erabili aldaera apikaria. Adinekoen artean, berriz, denetarik aurkitzen dela dio. Badirudi beraz, ahoskera frantsesa erabat nagusitzen ari dela Iparraldean.

\subsection{3. $[u] \rightarrow<i>I_{-}[a, e]$ arau aldagarria}

Hitzaren oinarria $u$-z finitzen denean, honi a edo $e$ bokala gehituz gero, $i$ bihur liteke Nafarroa Behere gehienean eta Zuberoan. Honela formula genezake (1) araua, Laboven metodologiari jarraituz (1972, 276-277. orr.): [u] $\rightarrow<\mathrm{i}>$ I_[a,e]. Hau da, [u] hotsa $<\mathrm{i}>$ bihur liteke [a] edota [e] baten aurretik badago. Labov-ek proposatutako arau aldagarriaren arabera, <> ikurren bidez, gauza litekeen hotsa adierazten ari gara, hau da, kasu honetan, [u] $\rightarrow$ [i] bagenu, [u] beti [i] bihurtzen dela ondorioztatuko genuke. Alta, [u] $\rightarrow$ $<\mathrm{i}>$ izanik, [i] bihur litekeela esaten ari gara, baina baita [u] bere horretan geldi litekeela ere. Dena dela, arau aldagarri honek, beste batzuekin duen harremana ere ulertu beharra dago, zein kasu kontuan hartu eta zein ez erabakitzeko. Esaterako, murru bat $\rightarrow$ murru at izatera igaro liteke, baina inolaz ere ez ondoren *murri at, hiztunen gogoan $[\beta]$ hots hori presente baitago, hizketa zainduan ongi aski kontserbatzen dena, eta ez, beraz, $u+$ a segidarik. Kaminok eta Salaberrik (2004, 93. orr.) diotenez, Luzaiden uia forma zaharragoa gordetzen da monosilaboetan eta biraoetan, $i a$ ordez, eta Garaziko gainerako herrietan ere ber egoera aurkitu dugu guk. Ondorengo kasuetan, berriz, ikerketan zehar ikusi ahal izan dugunaren arabera, ez da bilakabidea gertatzen: eskuara (euskara-ren metatesiz gertatua) eta honen eratorria den eskualduna, batzuetan, eguerdi, eta hiru + atzizkia. Hauek ez dira, beraz, kontuan hartu bilakabidea gertatzen den ala ez aztertzean. 


\subsubsection{Goranzko diptongoak}

Mitxelenaren (1990 [1977], 167. orr.) arabera, lehenengo osagaia [j] eta [w] duten goranzko diptongoak bigarren mailakoak dira gehienik euskaraz. Batez ere, erdal maileguetatik datoz, baina baita elkarrekin kontaktuan dauden bokaletarik ere. Euren maiztasuna ez da bera euskalki guztietan, eta autore honek dioenez, gipuzkera, bizkaiera eta zuberera dira honelako diptongoak gutxien onartzen dituztenak. Lapurteraz, behe-nafarreraz, zaraitzueraz eta erronkarieraz, berriz, ohikoak dira.

$i, u, e$ eta $o$ bokalekin osatutako goranzko diptongoak izango dira lan honetan kontuan hartuko ditugunak. Honela formula ditzakegu arau hauek.

a) (2) $[\mathrm{i}] \rightarrow<j>/[a, e, o, u]$

b) (3) $[u] \rightarrow<w>/ \_[a, e, i, o]$

c) (4) $[e] \rightarrow<i, e, j>/ \_[a]$

d) (5) $[\mathrm{o}] \rightarrow<\mathrm{O}, \mathrm{u}, \mathrm{W}>\mathrm{I}[\mathrm{a}]$

Lehen bien kasuan hierarkia bat proposatu beharra dugu arestiko arauarekiko. Lehenik, (1) araua aplikatzen dela deritzogu, eta bilakabide hau gertatzen ez bada, hau da, $u$ bere horretan gelditzen bada, gero $u$-rekin goranzko diptongoa gertatzen den ala ez ikusiko dugu. Bilakabidea gertatzen bada berriz, erran nahi baita, $[\mathrm{u}] \rightarrow[\mathrm{i}]$ bihurtzen, ondoren $i$ bokala hiato moduan gelditzen den ([i] moduan), edo goranzko diptongoa sortzen den, hots [j] bihurtzen den aztertuko da. Esaterako, demagun akitua hitza aztertu nahi dugula. Lehenik, beraz, hiztunak akitua edo akitia ahoskatzen duen ikusiko dugu. Lehen kasua baldin bada, akit [u]a edo akit [w] a ebakitzen duen aztertuko dugu, eta bigarren kasuan, berriz, akit [i]a edo akit[j]a ahoskatzen duen. Bestalde, erdaraz (gaztelaniaz nahiz frantsesez) diptongo hauek dituzten mailegu berrienak kontuan ez hartzea pentsatu dugu, izan ere, tradizionalki goranzko diptongorik ez den hizkeretan ere, mailegu berri hauetan, diptongo bezala gordetzea posible da. Erran beharra dugu lan honetan diptongoa eratzea ala ez eratzea posible duten eta elkarren segidan doazen bi bokal hartuko ditugula kontuan, eta ez hots baten galeraren ondorioz sortutako diptongoak, horiek azterketarako orduan zailtasunak ematen baitizkigute. Esaterako akit[w]ik hitza kontuan hartuz gero, horren baliokidea litzateke akit[u]ik aldaera ez diptongatua, baina baita akiturik ere, beraz ez geundeke aukera bitar baten aurrean.

\subsection{5. ( $t$ ) eta (d) aldagaiak}

Euskaraz, /t/ eta /d/ fonemak herskari horzkari ahoskatzen direla diote lan gehienek, esaterako Hualdek (1998 [1991], 15. orr.), baita apikari ere (Txillardegi, 1980, 87. orr.; Hualde, 2003). Gaur egun ordea, belaunaldi gazteenek Iparraldean bestelako ahoskune eta ahosmodua darabilte [i] eta [j] hotsak atzetik datozenean, frantsesaren eraginez nagusitzen doana. Honela deskribatzen du fenomenoa Poirier-ek (in Russell, 2010, 1358. orr.): «hersketaren laxatze progresiboa, kontsonantearen (geldiunearen) hondarreko zatia luzatzea ondoriotzat duena, horregatik hautematen dugu zarata igurzkari azkarra». Apikari terminoa erabiliko dugu, euskarazko jatorrizko hotsak adierazteko, hots, 
herskari, horzkari, apikariak. Lepokari terminoa erabiliko dugu berriz, frantsesetik heldu diren hots berriagoak adierazteko, hau da, aurreko hotsak baino afrikatuagoak, hobikariak eta lepokariak, [t] eta [d] moduan adierazten ahalko genituzkeenak. Ladefoged eta Maddieson-en arabera, hizkuntza batek kontsonante herskari apikaria eta lepokaria baditu, bigarrena afrikatuagoa izan ohi da (Ladefoged \& Maddieson, 1996, 23 orr.). Bien arteko desberdintasuna espektrogrametan ageri da, bigarren hotsak duen afrikazioa agerian gelditzen baita, hersketaren laxatzeak sortzen duen hots turbulentzia beti eta handiagoaren bitartez (Stevens, 1998, 422. orr.). Horrez gainera, bigarren taldeko hotsen hersketaren aurreko bigarren formakina lehenengo taldekoena baino baxuagoa da (Ladefoged \& Maddieson, 1996, 24. orr.).

\subsection{Aldagai sozialak edo aldagai askeak}

Adina eta generoaren araberako bariazioa ikertzea erabaki dugu lan honetan. Horrez gain, aldagai geografikoari ere, lekua egin diogu. Bestalde, lekukoak ikasketa-maila, ama-hizkuntza eta hezkuntza-eredu jakin batekoak izan daitezen saiatu gara, nahiz eta aldagai hauen araberako aldakortasunik ez aztertu.

\subsubsection{Adina}

Adinak hizkuntzaren aldaketan izan duen eragina, mende honetako bariazioaz ari izan diren lan gehienetan aztertu da, ez errateko guzietan.

Autore zenbaiten ustez, tartean Eckert (1997, 151. orr.), hizkuntza aldaera bat edo beste erabiltzean, eragina duena adinaren estatus biologikoa baino areago, gizartean duen estatusa da esanguratsu.

Garazi ibarrari dagokionez, adinekoak, ingurune erabat euskaldunean hazi eta hezi dira, \% 100 euskaldunetik hurbil dagoen gizartea ezagutu dute. Beraz, gaurko egunean ere, beraiek aitortzen diguten bezala, lehenik euskaraz pentsatzen dute anitzek, frantsesez mintzatu baino lehen. Jatorrizko euskal ahoskera hobekien kontserbatzen dutenak dira, eta gainera, ahoskera hori frantsesez mintzatzean ere ageri zaie.

Helduak, berriz, ingurune euskaldunean jaio dira, euskara mintzatzen duten guztiek etxean ikasi eta erabili dute, baina bizimodu modernoaren garapena ezagutu dute, erran nahi baita, ikasketa handiagoak egin dituzte, usu kolegiora joan izan dira Donibane Garazira, eta baita lizeora ere, zenbaiten kasuan. Telebista etxean sartzen ikusi dute, etxaldeko ateraino bidea egiten ezagutu dute, eta beraz, hiriburuekiko lotura hobea izaten hasi dira. Egoera ekonomikoa hobetzen ere ikusi dute, oro har. Bizimodu «berri» horretan, frantsesa beti eta presentzia handiagoa izaten hasi da, eta hori dela eta, zenbaitek euskara erabat bazter utzi dute euren eguneroko bizian, gurasoekiko harremanera mugatuz, eta batzuetan, ezta horretara ere.

Azkenik, gazte gehienak ez dira euskaraz mintzo, zailtasunak dituzte, edota badakite baina bakan baliatzen dute Garazin, iparralde osoan bezalatsu. Badira euskaraz bizi diren gazteak ere, euskara jakin eta erabiltzen dutenak, baina hauek ingurune frantses edo gaztelauan hazi dira, gizartearen parte handiena frantsesez edo gaztelaniaz bizitzen ezagutu 
dute, eta euskara, beraz, sortu duten euskaldun sare trinkoari esker erabiltzen dute, dela euskal kutsuko ostatuetan, euskal giroko festetan edota familian ere bai, zenbait kasutan.

Egoera soziolinguistiko desberdina kontuan hartuta, hiru adin talde banatzea iruditu zaigu onena. Bakoitzarendako 15 urteko adin tartea aukeratu dugu, eta adin talde batetik bestera hamar urteko tartea egotea deliberatu dugu. Beraz gauzak horrela, gazteak 18-33 urte bitartekoak lirateke, helduak 43-58 urte bitartekoak eta adinekoak berriz, 68 eta 83 urte artekoak.

\subsubsection{Generoa}

Hau ere soziolinguistika lan ugaritan aztertua izan den aldagaia dugu. Usu sexua aipatzen bada ere, McConnel-Ginet (1988) eta Eckertek (1989) sexua eta generoa bereiztea proposatu zuten. Lehenengoak ezaugarri biologikoak hartuko lituzke bere baitan, eta bigarrenak, berriz, ezaugarri soziokulturalak. Sexua, beraz, geneek aurredeterminatutako kategoria litzateke, norbanakoak jaio aurretik erabakita dagoena. Generoa, berriz, norbanakoa jaio ostean, kulturalki eraikia den kategoria litzateke, konbentzional edo arbitrarioa eta soziala. Gizonen eta emazteen arteko hizkuntza-desberdintasunen arrazoiak gizarte egoera desberdinetatik datozelako usteari jarraituz, gure lanean, generoaren aldeko hautua egitea erabaki dugu.

Tradizionalki, emakumeek gizonezkoek baino estigmatizatutako aldaera gutxiago darabiltzatela esan izan da, prestigiozko aldaeren alde eginez (Labov, 2001, 266. orr.), eta baita hedatzen dabiltzan aldaeren alde gizonezkoek baino nabarmenago egiten dutela ere (Labov, 2001, 274. orr.). Eckerten ustez, baieztapen hau ez da hatsarre konstante moduan ulertu behar, baizik eta emakumeek eta gizonek gizartean duten lekuari eskaini behar zaio arreta. Gauzak horrela, generoak eta hizkuntzak duten harremana kultura batetik bestera aldatu egiten dela azpimarratu du (Eckert, 1989, 248. orr.). Euskal Herrian kontrako joera ageri dela diosku Caminok (2009c, 299-300. orr.), hau da, emakumeak kontserbatzaileagoak direla. Joera horixe ageri da, Garazi bezala, ingurune rurala den Espainiako Zamorako Villadepera de Sayago herriko mintzoan ere (Borrego-Nieto, 1981, 15-16. orr.).

Garaziko ibarrean, adineko emakumeak etxean egon izan dira senideak zaintzen, eta mugikortasuna ia esklusiboki gizonezkoen pribilejioa izan da urte luzez. Gaur egunean, emakumeak lan merkatuan txertatu dira, baina ez dute gizonezkoen ber estatusa, eta generoen arteko bereizketa argia, nahiko errotua dago oraindik ere.

\subsubsection{Aldagai geografikoa}

Arrazoi sozio-kultural eta politikoetan oinarriturik, honako bost eremu hauek bereizi ahal izan ditugu geografikoki Garazi ibarrean:

1- Luzaide.

2- Arnegi aldea: Arnegi, Uharte-Garazi, Lasa, Azkarate, Anhauze eta Irulegi.

3- Ezterenzubi aldea: Ezterenzubi, Eiheralarre eta Zaro. 
4- Hergarai: Duzunaritze-Sarrasketa, Ahatsa-Altzieta-Bazkazane, Lekunberri, Mendibe, Aintzila eta Behorlegi.

5- Gamarte aldea: Izpura, Donazaharre, Jatsu, Buztintze-Iriberri, Suhuskune, Lakarra, Ainhiza-Monjolose eta Gamarte.

Luzaide lan honetan kontuan hartzea funtsezkoa iruditu zaigu, berriki arte, ibar honetan egin baitute bizia bertako biztanleek, eta mintzoa ere garaztarra dute. Mugaz bestalde kokatuta egoteak, ordea, ezin esan eraginik ez duenik, eta beraz, eremu beregain bezala, besteengandik aparte aztertzea deliberatu dugu.

Horrez gain, Donibane Garazi ibarreko hiriburua lan honetan kontuan ez hartzea erabaki dugu, bertan jaiotako adin batetik gorako hiztun euskaldunak topatzeko zailtasunak eraginda.

Praktikan, talde bakoitzaren barrenean, elkarrengandik hurbilen dauden herrietako hiztunak aukeratzea erabaki dugu, talde bakoitzean, multzo geografiko ahalik eta trinkoenak osatzeko asmoz.

Baldintza bezala, bertan sortuak izatea eskatu diegu hiztunei, euren herriko ordezkari izateko. Adineko eta helduen kasuan, herritik kanpora bizi badira, Garaziko ibarrean bizitzen jarraikitzea ere eskatu dugu, ez ordea gazteen kasuan, usu urrun bizi baitira hauetarik anitz gaur egunean, ikasketak direla eta, nahiz eta gero asteburuetan haien herrirat sartzen diren. Praktikan, nahiko hiztun gutxi izan dira herritik kanpora bizi direnak, gehienak gazteak.

Aldagai geografikoa kontuan hartzearen arrazoia ez da inongo momentutan hizkeren sailkapena egitea, baizik eta martxan dauden hizkuntza-bilakabideen kasuan, eremu jakin bat kontserbatzaileago edo berritzaileago den ikustea. Batez ere, Luzaideren kasua interesatzen zaigu, muga politikoak hizkuntzan nolako eragina duen ikusteko.

\subsubsection{Ikasketa-maila, ama-hizkuntza eta hezkuntza eredua}

Hauen araberako hizkuntza-aldakortasuna aztertu ez badugu ere, hautatu ditugun hiru aldagai askeek bestelako batzuen eraginik jaso ez dezaten, hiztun guztiek ikasketamaila berdinak edukitzea (adinekoek eta helduek baxorik ez edukitzea eta gazteek baxoa izatea), euskara ama-hizkuntzatzat izatea eta gazteen kasuan, hauek ikastolan ikasi izana hartu ditugu baldintzatzat. Azkenik, elkarrizketatutako hiztun heldu eta adineko ia guztiak laborariak izan dira.

\subsection{Garazi ibarra}

Garaziko ibarra Nafarroa Behereko hego-ekialdean dago kokatuta nagusiki, eta Luzaide herria, berriz, Nafarroa Garaiko Ipar ekialdean, Pirinioen iparraldean. Mugak erdi-erditik zeharkatzen badu ere, geografikoki, kulturalki, linguistikoki eta historikoki ibar bakarra osatu du eremu honek. Ibarrak kantonamendua osatu du orain dela 
urte gutxi arte, gaur egun, Euskal Mendialdea izatera igaro dena Baigorriko kantonamenduarekin eta Zuberoarekin batera, Frantziako lurralde-erreforma dela eta, kantonamenduak berrantolatzea gertatu delarik 2014. urtean. Bertako udalerriek GaraziBaigorri herri elkargoa osatzen dute, 2017. urtetik aurrera, Iparraldeko eremu osoa hartzen duen Euskal Hirigune Elkargoaren parte dena. Horrez gainera, Garazi Nafarroa Behereko eskualde historiko bat ere bada. Hiriburua Donibane Garazi du, eta hau, gainera, Nafarroa Behereko hiriburua da, nahiz eta administratiboki eta politikoki hiriburu izaera hori sinbolikoa baino ez izan.

Ekonomiari dagokionez, azpimarratzekoa da lehen sektoreak, batez ere abeltzaintzak ibarrean duen pisu nabarmena, aktibitate ekonomikoaren \% 50 baino gehiago hartzen baitu. Horrez gain, zerbitzuek ere pisu nabaria dute eskualdean, tartean ostalaritzak, Donibane Garazik duen turismo handia dela eta (Garazi-Baigorri herri elkargoa, 2017).

Garazi ibarrean, iparralde osoan bezala, euskararen galera ikaragarria izan da azken hamarkadetan. 1968ko erroldan oinarrituta, Pedro Irizarrek 1981ean, Euskal Herriko herri bakoitzeko euskaldun kopurua eman zuen argitara, eta \% 80tik gorako euskaldun kopurua zegoen ibarreko herri guztietan Uharte-Garazin salbu. 2011n, ordea, Datu Soziolinguistikoen Biltegiko datuei dagokienez, kopuru hori \% 52,1era jaitsia zen Nafarroa Behere eta Zubero osoa aintzat hartuz geroz.

Gutxi dira zinez Garaziko ibarrari buruz egin diren lan bariazionistak, eta dialektologia tradizionalaren ikuspuntutik ere ez da gauza handirik egin inguru honetan, nahiz eta diziplina hau gurean garatuago izan.

Nafarroa Behereko euskara bere osotasunean ikertu zuen Camino-k (1987, 2004), eta bertako hizkerak geroz eta hobeto ezagutzen dihardugu azken urteetan autore hau egiten ari den lan eskergari esker. Hor ditugu esaterako, Zuberoa ipar-mendebaldeko herrietako mintzoez idatzi zuen lana (Camino, 2009b), baita Oztibarreko euskarari buruz idatzi zuena ere (Camino, 2015a), eta Amikuzeko euskarari buruzko lan mardula ere hor dugu (2009a, 2015b, 2016). Bestalde ezin ahatz genezake ikuspuntu diakronikotik Nafarroa Behereko euskara zaharraz egin lana ere (Camino, 2008). Nahiz eta Iparralde osoa aintzat hartu, Garaziko euskarari buruzko informazio interesgarria ematen digu Bourciez Bildumako Euskal Atlasa-k (aurrerantzean BBEA) (Aurrekoetxea \& Videgain, 2004; Aurrekoetxea, Videgain \& Iglesias, 2004, 2005) eta baita Euskal Herri osoa aintzat hartzen duten EHHA eta EAS corpusek ere.

Garazi gure ibarrari dagokionez, Luzaiden egin dira ikerketarik gehienak. XIX. mendean jada, Bonapartek (1881) interesa erakutsi zuen herri honetako mintzoarekiko. Hor dugu Kamino eta Salaberrik (2007) egin Luzaideko euskararen hiztegia ere, eta FLV aldizkarian atera zenbait lan (2001a, 2001b, 2004, 2006). Baita Salaberrik Dialektologia gaiak liburuan argitaratutakoa ere (2000). Soziolinguistikaren aldetik, hor dugu Aurnague eta Duguineren lana (2004) Garazin euskarak duen jakintza eta erabilera maila neurtuz. Bariazonismoari hertsiago lotutako lana dugu Santaziliak (2009) Luzaiden egin zuena. 


\section{IKERKETA HIPOTESIAK}

Lan honetako hipotesi nagusia da Garaziko euskara aldaketa handia pairatzen ari dela. Hipotesi zehatzak berriz, aldaketa hori geografiaren, adinaren eta generoaren arabera gertatzen dela.

Geografiaren arabera, Luzaide gainerako Garaziko herrietarik bereiz gelditzen dabilela uste dugu, muga politikoak berebiziko garrantzia hartu baitu azken urteotan. Adinari dagokionez, belaunaldi bakoitzak oso harreman desberdinak bizi izan ditu euskararekiko eta erdararekiko (gaztelania nahiz frantsesa). Adinekoetatik gazteetara bidean, ingurune erabat euskalduna ezagutzen duen gizartetik, giro erabat erdaldundua ezagutu duen batera igaro gara, non euskara batuak geroz eta presentzia gehiago duen. Hori dela eta, adinekoek Garaziko euskararen ezaugarriei hobeto eusten dietela, eta gazteen mintzoan erdarek eta euskararen eredu estandarrak eragin handia dutela uste dugu. Azkenik, generoari dagokionez, adineko emazteek zuten mugikortasun faltari erreparatuz, eta oraingo emakumeek lan merkatuan duten estausa segurtatu beharra kontuan hartuta, lehenak gordetzaile eta bigarrenak berritzaile direla uste dugu.

\section{METODOLOGIA}

Metodologiari eskainitako atal honetan, datuak bildu, prozesatu eta aztertzeko erabili ditugun irizpideak azalduko ditugu.

\subsection{Datuak bildu}

Garazi osoko hiztun guztiak ezin elkarrizketatu, eta beraz, lagina hautatzera behartuak gaude. Zeregin honetarako, soziolinguistikan ausazko hautaketa eta zentzuzko hautaketa erabili izan dira. Bigarren metodoa da gaur egungo lanetan ia gehienik erabiltzen dena. Aldez aurretik, aztertuko ditugun kategoria sozialak zein izango diren erabakitzen da, gero talde bakoitzetik lekuko kopuru berdina aliritzira hautatzeko (Silva-Corvalán, 1988, 18. orr.). Guk metodo honen alde egin dugu, nahiz eta lekukoak hautatzerako orduan ikertzaileak ezagun eta lagunengana jo duen aholku eske, elkarrizketa egiteko prest leudekeen hiztunen kontaktua lortzeko asmoz, Milroy-k Belfasten, sare-sozialen araberako aldakortasuna ikertzean egin zuen antzera (Milroy, 1980). Guztira 30 lekuko aukeratu ditugu laginaren kopurua lan bakoitzaren helburuei eta ikertzailearen denborari eta ahal ekonomikoei egokitu behar zaielako usteari jarraiturik (Silva-Corvalán, 1988, 20. orr.). 6 lekuko eremu geografiko bakoitzeko, 10 lekuko adin tarteko, eta 15 na genero bakoitzeko.

Soziolinguisten helburua hizketa naturala biltzea izan da. Haatik, argi dago datuak nonbait bilduta gera daitezen, beharrezkoa dela grabagailu bat erabiltzea, eta honek beti eragiten du hiztunarengan halako presio bat. Labov-ek (1972, 266. orr.) arazo honi «behatzailearen paradoxa» deitu zion. Berau saihesteko hiztunak gure lagunak izatea, edota lagunen lagunak izatea bilatu dugu, eta euren etxean edo usu joaten diren ostaturen 
batean egin dugu elkarrizketa, guk ere bertan parte hartuz, beraiek testuinguru informalean eroso senti daitezen. Hiztun ugarik konfiantza edota hurbiltasuna eskatzen duten toka edo $x u k a$ bezalako tratamenduak gurekin erabiltzeak, eurengandik mintzo espontaneoa jaso dugulako ustea indartzen digu.

Aztergai ditugun hizkuntza aldaketak denbora errealean edota itxurazko denboran neur genitzake. Bigarren aterabidea da, gaur egun gehien erabiltzen dena, eta lan honetan ere erabili duguna. Kasu honetan, belaunaldi desberdinetako jendeen datuak neurtuko lirateke, eta horrela, gertatzen ari diren aldaketek zer norabide duten identifikatu eta etorkizunera begirako aurreikuspenak egin daitezke.

Informatzaileen mintzo naturala ikertzeko asmoz, elkarrizketa erdi-gidatua da aukeratu den bidea, hau da, aurretik prestatutako galdera zehatzak gabe, gai jakin batzuk aukeratu ditugu, eta horiek garatu, beti ere informatzaileak horietan hartutako bidea errespetatuz. Hiztunen bizia, eskola, giza-harremanak, festak, eta hizkuntza-jarrerak izan ditugu batez ere hizpide elkarrizketan. Dialektologia pertzeptiboa ere landu dugu, hiztunek euren euskararen inguruan duten kontzepzioa lantzeko eta Luzaide eta Garaziko gainerako herrien arteko harremanaz ere galdetu diegu.

Ikertzailea ikertzen ari den tokikoa bertakoa izatearen garrantziaz dihardu Etxebarriak (2000, 35-36. orr.). Kasu honetan, luzaz Azpeitian bizi izan den bergararra dugu, baina ia hiru urte daramagu Nafarroa Beherean bizitzen edota asteburu ugaritan gerturatzen, probintzia honetako bizian parte hartzen, baita Irulegiko irratian kolaborazioak egiten eta Garazi-Oztibarreko euskara egin ahala xehetasunez ikasten ere. Beraz, bertakoa ez izanik ere, ez dugu uste hango komunitatean arrotzak garenik.

Elkarrizketak ordenagailuaren bitartez grabatu ditugu, honi Sony markako mikrofonoa lotuz eta Audacity programa informatikoa erabiliz. Programa hau erraz eskura liteke, kitorik da, eta hizkuntzalaritzaz egiten diren lanetan ardura erabiltzen da. 44100 hz-ko maiztasunean egin ditugu grabaketak .wav formatuan.

\subsection{Datuak prozesatu}

Ondoren fonetika-fonologiako lanetan hain ohikoa den Praat programa (Boersma eta Weenink, 2016) erabili dugu hizkuntza-datuak anotatzeko, etiketatzeko eta transkribatzeko. Azken zeregin hau sinboloen bitartez gauzatu dugu, esaterako th sinboloak lekukoak herskari hasperenduna ahoskatu duela erran nahiko luke, eta th0-k berriz, ez duela hala ahoskatu.

Behin sinbolo guztiak idaztean, list aukeraren bitartez, sinboloen zerrenda osoa lortu dugu, eta hau excel-eko orri batean kopiatu, datu basea sortuz. Sinboloen bidez adierazitako hizkuntza-datuak geografiaren, adinaren eta generoaren arabera sailkatu ditugu eta jarraian, programa honetako iragazkia aukera erabilita, hizkuntza-ezaugarri bakoitzeko aldagai askeen araberako erabileraren kopuru absolutu eta ehunekoak lortu ahal izan ditugu. 


\subsection{Datuak aztertu}

Gure lanean, azterketa kuantitatiboa egiteko, SPSS programa estatistikoaren aldeko hautua egin dugu. Bildu ditugun datuak aztergai ditugun aldagaien arabera estatistikoki esanguratsuak diren edo ez ikusi dugu Khi karratuaren probaren bitartez. Aldakortasun positiboa $p$ 0,05 baino txikiagoa bada, aldagaien arabera datuetan dagoen aldea esanguratsua dela ondorioztatuko da, eta handiagoa bada berriz, ez dela esanguratsua. Informatzaileen araberako sailkapena egiteko, berriz, multzokatze-analisia egin dugu, dendogramen bidez, ward metodoa erabilita, baita analisi multidimentsionala ere.

\section{DATUEN AZTERKETA}

Atal honetan, bildu ditugun hizkuntza-datuak adinaren, generoaren eta geografiaren arabera aztertuko ditugu. Khi karratua frogaren arabera, estatistikoki aldeak esanguratsuak diren ala ez ere ikusiko dugu. Datuen kopuruak eta ehunekoak berriz, tauletan emango ditugu. Azkenik, informatzaileen sailkapena egingo dugu multzokatze-analisi eta analisi multidimentsionalaren bidez.

\subsection{Hasperena hitz hasieran}

Azpiatal honetan denetara hitz hasierako hasperenaren eta hasperen ezaren (hasperena esperoko genukeen lekuan) 4553 adibide atzeman ditugu. 1329 hasperen ebaki dira (\% 29,19), eta 3224 (\% 70,81) kasutan ez da hasperenik ahoskatu espero izango genukeen kasuetan. Adibide bat emate aldera, Luzaideko adineko emazteak emandako supertoken hau genuke: hemen eta emen.

Hitz hasierako hasperenaren burutzapen edo burutzapen eza aztertutako herrietan zer kopurutan gertatzen den erakusten da 1. taulan. Bertan agertzen diren aldeak estatistikoki esanguratsuak dira $X^{2}$ probaren arabera $\left(X^{2}=(\right.$ a.m.: 4$) 20,410 ; p=$ $0,000)$.

1. taula. Hitz hasierako hasperena ahoskatzearen eta ez ahoskatzearen kopuru eta ehunekoak geografiaren arabera

\begin{tabular}{|l|c|c|c|c|c|c|}
\hline & \multicolumn{2}{|c|}{ Bai } & \multicolumn{2}{c|}{ Ez } & \multicolumn{2}{c|}{ Orotara } \\
\hline Herria & kopurua & $\%$ & kopurua & $\%$ & kopurua & $\%$ \\
\hline Luzaide & 231 & 25,61 & 671 & 74,39 & 902 & 100 \\
\hline Arnegi & 219 & 26,1 & 620 & 73,9 & 839 & 100 \\
\hline Ezteren. & 329 & 31,57 & 713 & 68,43 & 1042 & 100 \\
\hline Hergarai & 234 & 28,47 & 588 & 71,53 & 822 & 100 \\
\hline Gamarte & 316 & 33,33 & 632 & 66,67 & 948 & 100 \\
\hline
\end{tabular}


Geografiaren araberako aldea esanguratsua da hitz hasierako hasperenaren ebakerari dagokionez, baina ikus dezakegun moduan, hala ere, ez da ikaragarria. Hasperen gehien ahoskatu den lekua genuke Gamarte, eta gutxien ahoskatu dena berriz, Luzaide.

Segidan, adinak hitz hasierako hasperenak ahoskatzean duen eragina ikusiko dugu. 2. taulan ahoskatze kopuruak eta ehunekoak ikusiko ditugu. Alde hauek estatistikoki esanguratsuak dira $\mathrm{X}^{2}$ probaren arabera $\left(\mathrm{X}^{2}=(\right.$ a.m.: 2$\left.) 841,356 ; \mathrm{p}=0,000\right)$.

2. taula. Hitz hasierako hasperena ahoskatzearen eta ez ahoskatzearen kopuru eta ehunekoak adinaren arabera

\begin{tabular}{|l|c|c|c|c|c|c|} 
& \multicolumn{2}{|c|}{ Bai } & \multicolumn{2}{c|}{ Ez } & \multicolumn{2}{c|}{ Orotara } \\
\hline Adina & kopurua & $\%$ & kopurua & $\%$ & kopurua & $\%$ \\
\hline Adinek. & 871 & 50,38 & 858 & 49,62 & 1729 & 100 \\
\hline Helduak & 432 & 28,37 & 1091 & 71,63 & 1523 & 100 \\
\hline Gazteak & 26 & 2 & 1275 & 98 & 1301 & 100 \\
\hline
\end{tabular}

Ikus dezakegun moduan, aldeak oso nabarmenak dira. Bi belaunalditan hitz hasierako hasperena osasun onean egotetik ia hilzorian egotera igaro baita. Antzeko ehunekoetan dabiltza hitz hasierako hasperena ahoskatzearen edo ez ahoskatzearen kopuruak adinekoetan, nahiko apaltzen dira helduen kasuan eta azkenik gazteen kasuan zerotik hurbil daude.

Segidan, 3. taulan, generoaren arabera hitz hasierako hasperena ebakitzearen kopurua nola aldatzen den ikusiko dugu. Hemen ikusten ahal den bezala, aldeak estatistikoki esanguratsuak dira $X^{2}$ probaren arabera $\left(X^{2}=(\right.$ a.m.: 1$\left.) 16,292 ; p=0,000\right)$.

3. taula. Hitz hasierako hasperena ahoskatzearen eta ez ahoskatzearen kopuru eta ehunekoak generoaren arabera

\begin{tabular}{|l|c|c|c|c|c|c|} 
& \multicolumn{2}{|c|}{ Bai } & \multicolumn{2}{c|}{ Ez } & \multicolumn{2}{c|}{ Orotara } \\
\hline Generoa & kopurua & $\%$ & kopurua & $\%$ & kopurua & $\%$ \\
\hline Emazte. & 670 & 32,15 & 1414 & 67,85 & 2084 & 100 \\
\hline Gizonez. & 659 & 26,69 & 1810 & 73,31 & 2469 & 100 \\
\hline
\end{tabular}

Aldeak esanguratsuak bai, baina oso nabarmenak ez izan arren, emazteak gordetzaileago ageri zaizkigu gizonezkoak baino, hizkuntz ezaugarri honi dagokionez.

Multzokatze-analisia eta analisi multidimentsionala egin eta, lehen ondorioa da gazte guztiek multzo bera osatzen dutela, ez baitute batere edo ia batere hasperenik ahoskatzen. Maila gorago batean hauekin batera doaz heldu zenbait (Hergaraiko biak, Ezterenzubiko gizon heldua eta Arnegiko emazte heldua) eta harrigarriki, baita Luzaideko adineko gizona ere. Beste muturrean, hasperena gehien ahoskatzen dutenak ditugu: Hergaraiko eta Gamarteko adineko emazteak eta baita Ezterenzubiko adineko gizona ere. Hauei lotzen zaizkie maila goragoan, adineko ia guztiak eta baita Arnegiko gizon 
heldua ere. Beste maila bat gorago igoz geroz, heldu gehienak batzen zaizkie, baita Arnegiko eta Gamarteko adineko gizonak ere. Batez ere, adin taldeen araberako multzokatze argia dagoela ikus genezake.

\subsection{Hasperena bokal artean}

Hitz hasierako hasperenaren ebakera aztertu dugu, eta orain berriz, hasperenarekin jarraituko badugu ere, bokal arteko testuinguruari erreparatuko diogu. Hasperenaren ebakitze edo ez ebakitzearen (ebakitzea esperoko genukeen kasuetan) adibideak 1572 izan dira denera. Horietarik 77 (\% 4,9) ebakitze izan ditugu eta 1495 ez ebakitze $(\% 95,1)$. Kasu honetan, Hergaraiko adineko gizonaren supertoken hau har genezake adibidetzat: ehunaindako eta eunaindako.

Geografiak bokal arteko hasperena ebakitzean duen eraginari buruz, esan behar da aldeak estatistikoki ez direla esanguratsuak $\mathrm{X}^{2}$ probaren arabera.

Adinaren arabera, hauxe genuke bokal arteko hasperenaren aldakortasuna kopuru absolutuetan eta ehunekoetan adierazita 4. taulan. Bertan ikus daitezkeen aldeak estatistikoki esanguratsuak dira $\mathrm{X}^{2}$ probaren arabera $\left(\mathrm{X}^{2}=(\mathrm{a} . \mathrm{m} .: 2) 85,312 ; \mathrm{p}=\right.$ $0,000)$.

4. taula. Bokal arteko hasperena ahoskatzearen eta ez ahoskatzearen kopuru eta ehunekoak adinaren arabera

\begin{tabular}{|l|c|c|c|c|c|c|} 
& \multicolumn{2}{|c|}{ Bai } & \multicolumn{2}{c|}{ Ez } & \multicolumn{2}{c|}{ Orotara } \\
\hline Adina & kopurua & $\%$ & kopurua & $\%$ & kopurua & $\%$ \\
\hline Adinek. & 63 & 11,75 & 473 & 88,25 & 536 & 100 \\
\hline Helduak & 14 & 2,43 & 561 & 97,57 & 575 & 100 \\
\hline Gazteak & 0 & 0 & 461 & 100 & 461 & 100 \\
\hline
\end{tabular}

Kasu honetan ere, adinekoak dira kontserbatzaileenak, baina hauek ere, bokal arteko hasperenaren adibide gutxi dituzte. Kopurua apaldu egiten da helduetan, gazteetan hasperenaren adibide bakar bat ere ez aurkitzeraino.

Generoari dagokionez, hitz hasierako hasperenaren kasuan ez bezala, kasu honetan generoaren araberako aldakortasuna ez da estatistikoki esanguratsua $\mathrm{X}^{2}$ probaren arabera $\left(X^{2}=(\right.$ a.m.: 1) 1,$003 ; p=0,317)$.

Multzokatze-analisia eta analisi multidimentsionala burutu ostean, Hergaraiko adineko emaztea da bokal arteko hasperen gehien ahoskatzen duena, eta bakarrik dago multzokatzearen mailarik oinarrizkoenean. Bigarren mailan, hitz hasierako hasperenaren kasuan bezala, hasperen ugari ahoskatu dituzten Gamarteko adineko emaztearekin eta Ezterenzubiko adineko gizonarekin doa, baita Arnegi aldeko adineko emaztearekin eta nahiko kontserbatzaile ageri den Gamarte aldeko gizon helduarekin ere. Gainerako hiztunak elkarrekin doaz multzokatzearen ezkerreko multzoan, hasperen gutxi edo bat ere ez dute ahoskatzen, alegia. Kopuru apalean ahoskatzen duten ia guztiak adinekoak 
dira, Luzaideko gizonezko heldua salbu. Ahoskatzen ez dutenen artean, helduak eta gazteak baino ez ditugu. Hitz hasierako hasperenaren kasuan bezalaxe, adinaren eragin handia nabari da.

\subsection{Herskari hasperendunak}

Azpi-atal honetan herskari hasperendunak aztertuko ditugu. Denera, herskari hasperenduna ahoskatu den eta ahoskatu ez den 1374 kasu bildu ditugu, horietatik bost herskari hasperendun (\% 0,36) baino ez dira ahoskatu ibar osoan, eta 1369 kasutan (\% $99,64)$ ez da ahoskatu. Hots hau ahoskatzearen adibidea genuke Gamarte aldeko gizon helduak ahoskatutako ithurria, eta ez ahoskatzearena ikusi.

Hizkuntza-ezaugarri honetan geografiak duen eragina aztertuko dugu lehenbizi. 5. taulan kopuruak eta ehunekoak erakutsiko ditugu. Geografiaren araberako aldeak estatistikoki esanguratsuak dira $X^{2}$ probaren arabera $\left(X^{2}=(\right.$ a.m.: 4$) 16,802 ; p$ $=0,002$ ).

5. taula. Herskari hasperenduna ahoskatzearen eta ez ahoskatzearen kopuru eta ehunekoak geografiaren arabera

\begin{tabular}{|l|c|c|c|c|c|c|} 
& \multicolumn{2}{|c|}{ Bai } & \multicolumn{2}{c|}{ Ez } & \multicolumn{2}{c|}{ Orotara } \\
\hline Herria & kopurua & $\%$ & kopurua & $\%$ & kopurua & $\%$ \\
\hline Luzaide & 0 & 0 & 278 & 100 & 278 & 100 \\
\hline Arnegi & 0 & 0 & 285 & 100 & 285 & 100 \\
\hline Ezteren. & 0 & 0 & 265 & 100 & 265 & 100 \\
\hline Hergarai & 0 & 0 & 230 & 100 & 230 & 100 \\
\hline Gamarte & 5 & 1,58 & 311 & 98,42 & 316 & 100 \\
\hline
\end{tabular}

Gamarte ingurua da herskari hasperendunak ahoskatzen dituen eremu geografiko bakarra, eta bertan ere ez dira ugari.

Adinaren araberako aldeak ez dira estatistikoki esanguratsuak $\mathrm{X}^{2}$ probaren arabera $\left(\mathrm{X}^{2}=(\right.$ a.m.: 2) 3,241; $\mathrm{p}=0,198)$.

Generoaren arabera ere, aldeak ez dira estatistikoki esanguratsuak $\mathrm{X}^{2}$ probaren arabera $\left(\mathrm{X}^{2}=(\right.$ a.m.: 1$)$ 0,234; $\left.\mathrm{p}=0,628\right)$.

Behin multzokatze-analisia eta analisi multidimentsionala eginda, ondorioa argia da: Gamarte aldean baino ez dira ahoskatzen herskari hasperendunak, eta oso kopuru apalean gainera, bertako adineko emaztea eta gizon heldua baino ez baitira ahoskatzen dutenak. Oztibarre eta Arberoan aise herskari hasperendun gehiago entzun izan dugu, eta Gamarte aldea ibar horietarik hurbil egoteak azal lezake segurrenik ere, inguru honetan adibide bakarrok aurkitzea. 


\subsection{Dardarkariak}

Azpiatal honetan denetara 6340 dardarkari jaso dira. Hauetariko 2241 (\% 35,3) apikariak izan dira eta 4099 (\% 64,7) ubularrak. Dardarkarien supertoken esanguratsua genuke Ezterenzubiko adineko emaztearena: be[r]din eta be[R]din.

Soinu bakoitzaren banaketa aukeratu ditugun herrien arabera erakusten da 6. taulan. Bertan ikus daitezkeen aldeak estatistikoki esanguratsuak dira $\mathrm{X}^{2}$ probaren arabera $\left(\mathrm{X}^{2}=(\right.$ a.m.: 4) 3091,466; $\mathrm{p}=0,000)$.

6. taula. Dardarkari apikari eta ubularren kopuru eta ehunekoak geografiaren arabera

\begin{tabular}{|l|c|c|c|c|c|c|}
\hline & \multicolumn{2}{|c|}{ Bai } & \multicolumn{2}{c|}{ Ez } & \multicolumn{2}{c|}{ Orotara } \\
\hline Herria & kopurua & $\%$ & kopurua & $\%$ & kopurua & $\%$ \\
\hline Luzaide & 1167 & 100 & 0 & 0 & 1167 & 100 \\
\hline Arnegi & 409 & 20,56 & 790 & 65,89 & 1199 & 100 \\
\hline Ezteren. & 24 & 0,85 & 1400 & 98.31 & 1424 & 100 \\
\hline Hergarai & 165 & 7,31 & 1046 & 86,37 & 1211 & 100 \\
\hline Gamarte & 476 & 21,62 & 863 & 64,45 & 1339 & 100 \\
\hline
\end{tabular}

Ondorio interesgarriak atera genitzake ikusitakoa ikusita. Alde batetik deigarria da Luzaiden ez dugula dardarkari ubularraren adibide bakar bat ere, hango erdara nagusia den gaztelaniak ere ez duelako. Beste gainerako herri guztietan, frantsesa baita erdara nagusia, sartuxe dugu ahoskera mota hau. Arnegi eta Gamarte aldea dira hots apikaria hobekien kontserbatzen dutenak, eta deigarria da Ezterenzubi bezalako leku bakartu batean dardarkari apikariak hain presentzia apala izatea.

Adinaren araberako emaitzak 7. taulan erakusten dira. Bertan ikus daitezkeen aldeak estatistikoki esanguratsuak dira $X^{2}$ probaren arabera $\left(X^{2}=(\right.$ a.m.: 2$) 1306,071 ; p=$ $0,000)$.

7. taula. Dardarkari apikari eta ubularren kopuru eta ehunekoak adinaren arabera

\begin{tabular}{|l|c|c|c|c|c|c|}
\hline & \multicolumn{2}{|c|}{ Apikaria } & \multicolumn{2}{c|}{ Ubularra } & \multicolumn{2}{c|}{ Orotara } \\
\hline Adina & kopurua & $\%$ & kopurua & $\%$ & kopurua & $\%$ \\
\hline Adinekoak & 1466 & 64,16 & 819 & 35,84 & 2285 & 100 \\
\hline Helduak & 433 & 21,29 & 1601 & 78,71 & 2034 & 100 \\
\hline Gazteak & 342 & 16,92 & 1679 & 83,08 & 2021 & 100 \\
\hline
\end{tabular}

Adinekoetan, ahoskera apikaria aise nagusitzen zaio oraino ere ubularrari Garazin. Helduetan apikaria ahoskatzen duten ia gehienak Luzaidarrak ditugu baina beste herrietan ere aurki genitzake adibide banaka batzuk. Azkenik, ahoskera apikaria duten 
gazte guztiak luzaidarrak dira. Luzaidarrak aparte utzirik, gazte eta heldu guztiek darabilte dardarkari ubularra, azken adin talde honetan aldaera apikariaren adibide bakarren bat dagoen arren. Horrek belaunaldi desberdinen artean, sekulako aldaketa egon dela esan nahi du.

Generoari heldu zaionez, honek dardakari bat edo beste ahoskatzean duen eragina zer heinetakoa den erakutsiko dugu 8. taulan. Aldeak estatistikoki esanguratsuak dira $\mathrm{X}^{2}$ probaren arabera $\left(\mathrm{X}^{2}=(\mathrm{a} . \mathrm{m} .: 1) 137,300 ; \mathrm{p}=0,000\right)$.

8. taula. Dardarkari apikari eta ubularren kopuru eta ehunekoak generoaren arabera

\begin{tabular}{|l|c|c|c|c|c|c|} 
& \multicolumn{2}{|c|}{ Bai } & \multicolumn{2}{c|}{ Ez } & \multicolumn{2}{c|}{ Orotara } \\
\hline Generoa & kopurua & $\%$ & kopurua & $\%$ & kopurua & $\%$ \\
\hline Emazte. & 1302 & 42,65 & 1751 & 57,35 & 3053 & 100 \\
\hline Gizonez. & 939 & 28,57 & 2348 & 71,43 & 3287 & 100 \\
\hline
\end{tabular}

Bi generoen arteko aldea nabarmena da, emazteek aldaera apikariaren aldeko joera handiagoa baitute. Alde hori adinekoetan dagoela azpimarratu behar litzateke, luzaidarrak salbu, helduek eta gazteek aldaera ubularra ahoskatzen baitute ia $\%$ 100ean.

Aldagai honen araberako hiztunen sailkapen orokorrari dagokionez, bai multzokatze-analisia, bai analisi multidimentsionala eginda, bi multzo oso argi aurki genitzake dardarkariei dagokienez: apikari ahoskatzen dutenak eta ubular ahoskatzen dutenak. Lehen multzo honetan luzaidar guztiak, Gamarte aldeko eta Arnegiko adinekoak eta Hergaraiko adineko emaztea aurki genitzake. Bigarren multzoan beste guztiak ditugu. Horietarik batzuek, batez ere adineko eta helduek dardarkari apikariaren adibide batzuk dituzte, baina oso gutxi, gehienik, Ezterenzubiko adineko emazteak. Badirudi aldaketa honen kasuan, muga politikoak berebiziko garrantzia izan duela, Luzaide mugaz bestalde egoteak sekulako barrera suposatu duelako dardarkari ubularra bertara sartzeko.

\section{5. (1) araua $([\mathrm{u}] \rightarrow<\mathrm{i}>/[[\mathrm{a}, \mathrm{e}])$}

Jarraian (1) arauaren datuak aztertuko ditugu. Denera, araua gauzatzearen eta ez gauzatzearen 1608 adibide bildu ditugu. Horietarik, 1475 (\% 91,73) kasutan araua gauzatu da, eta beraz, [i] ukan dugu. 133 (\% 8,27) kasutan berriz, araua ez da gauzatu eta beraz, $[\mathrm{u}]$ dugu. Hergaraiko mutil gazteak supertoken adibide hau dakar: nien eta nuen.

Geografiak hizkuntza-ezaugarri honetan duen eragina aztertu dugu, eta emaitzak 9. taulan doaz. Aldeak estatistikoki esanguratsuak dira $\mathrm{X}^{2}$ probaren arabera $\left(\mathrm{X}^{2}=(\mathrm{a} . \mathrm{m}\right.$. : 4) 44,$912 ; \mathrm{p}=0,000)$. 
9. taula. (1) araua gauzatzearen eta ez gauzatzearen kopuru eta ehunekoak geografiaren arabera

\begin{tabular}{|l|c|c|c|c|c|c|}
\hline & \multicolumn{2}{|c|}{ Bai } & \multicolumn{2}{c|}{ Ez } & \multicolumn{2}{c|}{ Orotara } \\
\hline Herria & kopurua & $\%$ & kopurua & $\%$ & kopurua & $\%$ \\
\hline Luzaide & 340 & 92,9 & 26 & 7,1 & 366 & 100 \\
\hline Arnegi & 290 & 95,71 & 13 & 4,29 & 303 & 100 \\
\hline Ezteren. & 317 & 94,91 & 17 & 5,09 & 334 & 100 \\
\hline Hergarai & 211 & 93,36 & 15 & 6,64 & 226 & 100 \\
\hline Gamarte & 317 & 83,64 & 62 & 16,36 & 379 & 100 \\
\hline
\end{tabular}

Orain arteko datuei dagokienez, nahiko kontserbatzaile agertu zaigu Gamarte aldea, baina kasu honetan kontrako joera ageri du, berritzaileago baita.

Adina da orain aztergai dugun aldagai askea, eta honek aztergai dugun (1) arauan duen eragina ere izartu dugu. 10. taulan dakuskigun hauexek dira adinaren araberako datuen kopuruak eta ehunekoak. Batetik besterako aldea estatistikoki esanguratsua da $\mathrm{X}^{2}$ probaren arabera $\left(\mathrm{X}^{2}=(\right.$ a.m.: 2$\left.) 286,021 ; \mathrm{p}=0,000\right)$.

10. taula. (1) araua gauzatzearen eta ez gauzatzearen kopuru eta ehunekoak adinaren arabera

\begin{tabular}{|l|c|c|c|c|c|c|}
\hline & \multicolumn{2}{|c|}{ Bai } & \multicolumn{2}{c|}{ Ez } & \multicolumn{2}{c|}{ Orotara } \\
\hline Adina & kopurua & $\%$ & kopurua & $\%$ & kopurua & $\%$ \\
\hline Adinek. & 623 & 100 & 0 & 0 & 623 & 100 \\
\hline Helduak & 550 & 97 & 17 & 3 & 567 & 100 \\
\hline Gazteak & 302 & 72,25 & 116 & 27,75 & 418 & 100 \\
\hline
\end{tabular}

10. taula honetan, argi ageri zaigu adinekoek beti gauzatzen dutela bilakabide hau, helduetan hasten zaizkigu bilakabidea ez gauzatzearen lehen adibideak, gazteen kasuan, erabat ugaritzeko. Ikastoletan erakusten den euskararen aldaera estandarrak ez du bilakabide hau ezagutzen. Horrez gain, garaztarrek ahozko erregistroarekin lotzen dute, beraz ez dute idatzian erabiltzen. Gauzak horrela, dudarik gabe, ikastoletan gazteek ikasi duten euskara batuak eta euskara idatziak berebiziko garrantzia dute bilakabide honen atzerakadan.

Generoa aldagai askearen araberako aldea ez da estatistikoki esanguratsua $\mathrm{X}^{2}$ probaren arabera $\left(\mathrm{X}^{2}=(\right.$ a.m.: 1$\left.) 0,111 ; \mathrm{p}=0,739\right)$.

Multzokatze-analisiko eta analisi multidimentsionaleko emaitzak ikusita, multzorik handienean, bilakabidea erabat edo oso ehuneko handian gauzatzen duten hiztunak ikusten ditugu. Beste multzo batean berriz, kasuen erditsutan bilakabidea gauzatzen duten eta beste erditsutan gauzatzen ez duten hiztunak ditugu. Denak gazteak dira bertan, eta Hergaraiko emazte heldua ere bertan dugu, berritzaile ageri dena. Azkenik, Arnegi aldeko eta Gamarte aldeko gizon gazteek multzo bakarra osatzen dute, oso kasu gutxitan edo inoiz ere ez baitute gauzatzen bilakabidea. 


\subsection{Goranzko diptongoak: (2) araua $([\mathrm{i}] \rightarrow<j>/[[a, e, o, u])$}

Goranzko diptongoak aztertzen hasiz, lehenik eta behin, $i$-ri eskainiko diogu arreta. Erran dugun moduan, bokal baten aurretik, zenbait aldiz, goranzko diptongoa sortzen $\mathrm{da}$, [j] erdi-kontsonantea hain zuzen ere, baina beste batzuetan, bokal izaera kontserbatzen du, [i]-k bere horretan segituz. Bilakabide hau gauzatzearen edota ez gauzatzearen 2776 adibide jaso ditugu, 2554 (\% 92) kasutan bilakabidea gauzatu da, eta $222(\%$ 8) kasutan berriz ez. Hergaraiko gizon helduaren supertoken hau har dezagun adibidetzat: antx[j]a eta antx[i]a.

Geografiaren araberako aldea ez da estatistikoki esanguratsua $\mathrm{X}^{2}$ probaren arabera $\left(X^{2}=(a . m .:\right.$ 4) 9,109; $p=0,058)$.

Adinaren araberako aldea ere ez da estatistikoki esanguratsua $\mathrm{X}^{2}$ probaren arabera $\left(\mathrm{X}^{2}=(\right.$ a.m.: 2) 2,599; $\mathrm{p}=0,273)$.

Azkenik, generoari erreparatuz, aldagai honen araberako aldea ere ez da estatistikoki esanguratsua $\mathrm{X}^{2}$ probaren arabera $\left(\mathrm{X}^{2}=(\mathrm{a} . \mathrm{m} .:\right.$ 1) 1,$195 ; \mathrm{p}=0,274)$.

Multzokatze-analisiari eta analisi multidimentsionalari erreparatu ostean, estatistikaren emaitzek adierazten duten moduan, argi ikusten da multzoak ez direla ez geografiaren, ez adinaren eta ezta generoaren arabera ere bereizten.

\subsection{Goranzko diptongoak: (3) araua $([\mathrm{u}] \rightarrow<\mathrm{w}>$ I_[a, e, i, o])}

Goranzko diptongoekin jarraituz, $u$ bokalarekin sortutakoak aztertuko ditugu ondoren. Zenbait aldiz, goranzko diptongoa sortzen da $[\mathrm{u}]$ hotsa ondoren datorren beste bokal batekin elkartuz, $[\mathrm{w}]$ emanez. Bilakabidea gertatzen ez denean, ordea, $[\mathrm{u}]$ bere horretan gelditzen da. 354 adibide bidu ditugu orotara. Horietarik, 311 (\% 87,85) kasutan bilakabidea gauzatu da, eta $43 \tan (\% 12,15)$ berriz, ez. Nahiko kopuru apala dugu, izan ere, ikusi dugun bezala, [u] gehienak [i] bihurtzen dira Garazin, salbuespen jakin batzuetan izan ezik. Gauzak horrela, salbuespen horiek edota (1) araua ahoskatzen ez den kasuak baino ez ditugu bilakabide hau aztertzeko. Bilakabidea ahoskatzearen adibidea genuke Arnegi aldeko mutilaren esk[w]a, eta ez egitearena berriz, gat $[u] a$.

Geografiaren araberako aldeak ez dira estatistikoki esanguratsuak $\mathrm{X}^{2}$ probaren arabera $\left(\mathrm{X}^{2}=(\right.$ a.m.: 4) 5,163; $\mathrm{p}=0,271)$.

Adinari erreparatuz, honen araberako hizkuntza-datuak aurkeztuko ditugu ondoren. Kopuruak eta ehunekoak 11. taulan dauzkagu. Aldea estatistikoki esanguratsua da $\mathrm{X}^{2}$ probaren arabera $\left(\mathrm{X}^{2}=(\right.$ a.m.: 2$\left.) 15,068 ; \mathrm{p}=0,001\right)$. 
11. taula. (3) arauaren ahoskatze eta ez ahoskatze kopuru eta ehunekoak adinaren arabera

\begin{tabular}{|l|c|c|c|c|c|c|}
\hline & \multicolumn{2}{|c|}{ Bai } & \multicolumn{2}{c|}{ Ez } & \multicolumn{2}{c|}{ Orotara } \\
\hline Adina & kopurua & $\%$ & kopurua & $\%$ & kopurua & $\%$ \\
\hline Adinek. & 111 & 97,37 & 3 & 2,63 & 114 & 100 \\
\hline Helduak & 73 & 85,88 & 12 & 14,12 & 85 & 100 \\
\hline Gazteak & 127 & 81,94 & 28 & 18,06 & 155 & 100 \\
\hline
\end{tabular}

Bertan ikus dezakegun moduan, adinekoetan bilakabidea ia-ia beti gertatzen da, baina apaltze nabarmena gertatzen da helduen kasuan, gazteetan areagotzeko. Gaztelaniaz eta frantsesez baditugu [w]-rekin osatuak diren diptongoak, baina erdialdeko euskaran oinarritua den euskara batuan ez dira hain ohikoak. Hori dela eta, diptongatzea ez gertatzeko joera ari da handitzen emeki-emeki.

Bi generoen arteko aldea ez da estatistikoki esanguratsua $\mathrm{X}^{2}$ probaren arabera $\left(\mathrm{X}^{2}=\right.$ (a.m.: 1) 2,746; $\mathrm{p}=0,097$ ).

Multzokatze-analisiko eta analisi multidimentsionaleko emaitzak aztertuta, lehenik eta behin, erran behar dugu bilakabide honen kasuan nahiko adibide gutxi ditugula, eta beraz horrek ondorio ziurrak ateratzeko zailtasunak ematen dizkigula. Bilakabidea gehien ahoskatzen dutenen kasuan, bi multzo ditugu, baita bilakabidea gutxien ahoskatzen dutenen kasuan ere. Lehenbizikoan adinekoak eta helduak ditugu gehienik, baina baita gazte batzuk ere: Hergaraikoak kontserbatzaile ageri zaizkigu kasu honetan, Luzaideko gizon gaztea eta maila apalagoan, baita Arnegiko gizon gaztea ere. Bilakabide gutxien ahoskatzen dutenen kasuan berriz, gazteak ditugu gehienik, baita heldu zenbait ere. Ezterenzubiko adineko emaztea harrigarriki, bilakabidea gutxien ahoskatzen duena dugu, eta berarekin multzo berean ditugu Ezterenzubiko neska gaztea, baita beste kasu batzuetan bezala berritzaile ageri zaigun Hergaraiko emazte heldua ere.

\subsection{Goranzko diptongoak: (4) araua ([e] $\rightarrow<\mathrm{i}, \mathrm{e}, \mathrm{j}>/[[\mathrm{a}])$}

Arestian azaldu dugun moduan, $e$ bokalak $a$ bokalarekin elkartu eta goranzko diptongoa osatzean, hiru emaitza hauek izan genitzake: [e] aldaera ez silabagilea, [i] bokal silabagilea, edota [j] ez silabagilea. Bilakabidea ahoskatzen ez bada, [e] silabagilea izaten jarraitzen du. Denera, 1176 adibide jaso ditugu. Horietarik, 79tan $(\%$ 6,72) [e] dugu, 363tan [e] (\% 30,87), 694tan [j] (\% 59,01), eta 40tan [i] (\% 3,4). Bilakabie honi dagokionez, Hergaraiko mutil gaztearen supertoken hau genuke: etx[e]a eta etx[j]a. [e]ri dagokion adibide hau ere badu: best[e $] a$. Arnegi aldeko adineko emazteak beste hau ere badakar: etxekander[i]a.

Geografiari erreparatzen hasita, hona hemen honen araberako hizkuntza-ezaugarri honen datu kopurua eta ehunekoak 12. taulan. Aldeak estatistikoki esanguratsuak dira $\mathrm{X}^{2}$ probaren arabera $\left(\mathrm{X}^{2}=(\right.$ a.m.: 12$\left.) 42,021 ; \mathrm{p}=0,000\right)$. 
12. taula. (4) arauaren ahoskatze eta ez ahoskatze kopuru eta ehunekoak geografiaren arabera

\begin{tabular}{|l|c|c|c|c|c|c|c|c|c|c|}
\hline & \multicolumn{2}{|c|}{$[\mathrm{e}]$} & \multicolumn{2}{c|}{$[\mathrm{i}]$} & \multicolumn{2}{c|}{ [e] } & \multicolumn{3}{c|}{ [j] } & \multicolumn{2}{c|}{ Orotara } \\
\hline Herria & Kop. & $\%$ & Kop. & $\%$ & Kop. & $\%$ & Kop. & $\%$ & Kop. & $\%$ \\
\hline Luzaide & 10 & 3,51 & 10 & 3,51 & 98 & 34,39 & 167 & 58,6 & 285 & 100 \\
\hline Arnegi & 22 & 10,58 & 10 & 4,81 & 77 & 37,02 & 99 & 47,6 & 208 & 100 \\
\hline Ezter. & 13 & 5,63 & 6 & 2,6 & 53 & 22,94 & 159 & 68,83 & 231 & 100 \\
\hline Herg. & 12 & 6,15 & 9 & 4,62 & 43 & 22,05 & 131 & 67,18 & 195 & 100 \\
\hline Gamar. & 22 & 8,56 & 5 & 1,95 & 92 & 35,8 & 138 & 53,7 & 257 & 100 \\
\hline
\end{tabular}

[j] da eremu guztietan nagusi den hotsa, ondoren dator [e], gero [e], eta azkenik [i]. Alta, badira ahoskatze kopuruetan alde zenbait: Luzaiden [e] eta [i]-k ahoskatze kopuru berdina dute. Ezterenzubin, eta maila apalxeagoan, Hergarain ere, [i]-ren aldeko joera handiagoa da beste eremuetan baino. Arnegi aldean eta maila apalagoan Luzaiden eta Gamarte aldean berriz, [e]-k indar aski handia du. Horrez gain, azpimarratzekoa da beste eremuekin konparatuta [e] aldaerak Arnegi aldean duen agerpen ehuneko handiagoa ere.

Adinari heldu zaionez, segidan (4) arauaren emaitzen kopuruak eta ehunekoak aztertuko ditugu adin talde desberdinen arabera. 13. taulan kopuruak eta ehunekoak ikusiko ditugu. Aldeak estatistikoki esanguratsuak dira $\mathrm{X}^{2}$ probaren arabera $\left(\mathrm{X}^{2}=(\mathrm{a} . \mathrm{m}\right.$. : 6) 274,$370 ; \mathrm{p}=0,000)$.

13. taula. (4) arauaren ahoskatze eta ez ahoskatze kopuru eta ehunekoak adinaren arabera

\begin{tabular}{|c|c|c|c|c|c|c|c|c|c|c|}
\hline & \multicolumn{2}{|c|}{ [e] } & \multicolumn{2}{|c|}{ [i] } & \multicolumn{2}{|c|}{ [e्a] } & \multicolumn{2}{|c|}{ [j] } & \multicolumn{2}{|c|}{ Orotara } \\
\hline Adina & Kop. & $\%$ & Kop. & $\%$ & Kop. & $\%$ & Kop. & $\%$ & Kop. & $\%$ \\
\hline Adin. & 11 & 2,53 & 23 & 5,3 & 94 & 21,66 & 306 & 70,51 & 434 & 100 \\
\hline Held. & 14 & 3,89 & 15 & 4,17 & 53 & 14,72 & 278 & 77,22 & 360 & 100 \\
\hline Gazt. & 54 & 14,14 & 2 & 0,52 & 216 & 56,54 & 110 & 28,8 & 382 & 100 \\
\hline
\end{tabular}

Datu interesgarriak dira biziki bilakabide honi dagozkionak. Aldeak ez dira hain handiak adinekoen eta helduen artean, baina helduen eta gazteen artean oso nabarmenak dira. Aldaera silabagileei dagokienez, [e]-ri dagokionez, erabilera oso apala du adinekoen artean, eta baita helduen kasuan ere, zertxobait handiagoa bada ere. Gazteen artean da era nabarmenean igotzen. [i]-ren erabilera apala baina nahiko antzekoa da adinekoen eta helduen kasuan, baina ia desagertzeraino jaisten da gazteen kasuan.

Aldaera ez silabagileei dagokienez, berriz, adinekoen artean, [j]-ren aldeko joera da nagusi, nahiz eta [e]-ren erabilera ere ez den txikia. Helduen kasuan berriz, hasieran kontrakoa espero bagenuen ere, [j]-ren erabilerak hazten jarraitzen du [e]-ren kaltetan, beraz indartzen doan ezaugarri bat litzateke. Gazteen kasuan ordea, egoera erabat itzulikatzen da: [e]-k hartzen du nagusitasun osoa, [j]-ren kopurua erabat jaitsiz. Euskara batuak ez du kasu hauetan [i] edo [j] aldaerarik ezagutzen, eta gazteak izan dira 
euskararen aldaera honekin kontakturik handiena izan duen adin taldea, besteak beste, ikastolaren bidez. Beraz, horrek azalduko luke adin talde hau izatea aldaera horiek gutxien ahoskatzen dituena, besteekiko alde handiarekin, gainera.

Emazteen eta gizonen arteko aldea estatistikoki ez da esanguratsua $\mathrm{X}^{2}$ probaren arabera $\left(\mathrm{X}^{2}=(\right.$ a.m.: 3) 1,$102 ; \mathrm{p}=0,777)$.

Multzokatze-analisian eta analisi multidimentsionalean, [j] aldaeraren aldeko joera duten bi multzo bereiz litezke. Batean, joera hori nabarmena da, maila askoz ere apalagoan [e] ahoskatu dute, eta azkenik, [e] eta [i] aldaerak oso kopuru apaletan. Bigarrenean, berriz, gehienbat [j] ahoskatzen badute ere, [e]-k pisu handiagoa du, eta kasu batzuetan baita [e] edota [i]-k ere. Bi multzo hauetan adinekoak eta helduak ditugu, eta bigarren multzoan, baita gazte batzu ere, beste kasu batzuetan ere kontserbatzaile agertu diren hergaraitarrak, Ezterenzubiko gizon gaztea eta Luzaideko emazteki gaztea. Aipatu bi multzo hauetarik landa, beste bat ere bereiz genezake, eta bertan, kontrako egoera ageri da, [e]-k hartzen baitu nagusitasuna [j]-ren aitzinean. [e]-k ere pisu nabaria du hiztun batzuen kasuan, baina [e]-ren heinera heldu gabe, hala ere. Talde honetan denak gazteak ditugu, tartean, beste ezaugarri batzuetan ere berritzaile ageri zaizkigun Gamarte aldekoak eta Arnegiko gizon gaztea. Gauzak horrela, euskara batua edo idatziaren eragina eztabaidaezina dela erranen genuke.

\subsection{Goranzko diptongoak: $(5)$ araua $([o] \rightarrow<o, u, w>I[[a])$}

Azken goranzko diptongoa aztertuko dugu ondorengo lerrootan, o-ri dagokiona, hain zuzen ere. Ondotik, [a] bokala heldu delarik, silabagiletasuna gal lezake [o] edota [w] bihurtuz. Bilakabidea gertatzen ez denean, [o] soila genuke, eta bestalde, [e] $\rightarrow[\mathrm{i}]$ gertatzen den bezalaxe, kasu honetan ere, [u] silabagilearen aukera aintzat hartu badugu ere, ez dugu horrelakorik aurkitu gure corpusean. Orotarat 1063 kasu aurkitu ditugu. Horietarik, $71(\%$ 6,68) [o] izan dira, $987(\%$ 92,85) [o] eta $5[\mathrm{w}](\%$ 0,47). Honako supertokena ahoskatu zuen Gamarte aldeko gizon helduak: errik[o]ak eta herrik[o]ak. [w]-ren adibide hau eman zuen berriz, Arnegi aldeko adineko emazteak: hang[w]a.

Hizkuntz ezaugarri honi helduz, geografiari dagokionez, kasu honetan ere baditugu aldeak. 14. taulan daude kopuruak eta ehunekoak. Aldea estatistikoki esanguratsua da $\mathrm{X}^{2}$ probaren arabera $\left(\mathrm{X}^{2}=(\right.$ a.m.: 8$\left.) 18,772 ; \mathrm{p}=0,016\right)$.

14. taula. (5) arauaren ahoskatze eta ez ahoskatze kopuru eta ehunekoak geografiaren arabera

\begin{tabular}{|l|c|c|c|c|c|c|c|c|} 
& \multicolumn{2}{|c|}{$[\mathbf{o}]$} & \multicolumn{2}{c|}{$[\mathbf{0}]$} & \multicolumn{2}{c|}{$[\mathbf{w}]$} & \multicolumn{2}{c|}{ Orotara } \\
\hline Herria & Kop. & $\%$ & Kop. & $\%$ & Kop. & $\%$ & Kop. & $\%$ \\
\hline Luzaide & 10 & 3,75 & 257 & 96,25 & 0 & 0 & 267 & 100 \\
\hline Arnegi & 24 & 11,01 & 192 & 88,07 & 2 & 0,92 & 218 & 100 \\
\hline Ezter. & 12 & 6,82 & 164 & 93,18 & 0 & 0 & 176 & 100 \\
\hline Herg. & 13 & 6,74 & 180 & 93,26 & 0 & 0 & 193 & 100 \\
\hline Gamar. & 12 & 5,74 & 194 & 92,82 & 3 & 1,44 & 209 & 100 \\
\hline
\end{tabular}


Arnegin ageri da [o] gehienik, eta Luzaiden berriz, gutxien. [w]-ri dagokionez, Arnegi aldean eta Gamarte aldean baino ez da agertzen, biziki kopuru apaletan.

Adina hartuko dugu kontuan jarraian. Honen arabera, bilakabidea gertatzen den eta zein emaitza duen ikusiko dugu. 15. taulan kopuruak eta ehunekoak ageri dira. Aldea estatistikoki esanguratsua da $\mathrm{X}^{2}$ probaren arabera $\left(\mathrm{X}^{2}=(\right.$ a.m.: 4) 25,$443 ; \mathrm{p}=0,000)$.

15. taula. (5) arauaren ahoskatze eta ez ahoskatze kopuru eta ehunekoak adinaren arabera

\begin{tabular}{|l|c|c|c|c|c|c|c|c|}
\hline & \multicolumn{2}{|c|}{ [o] } & \multicolumn{2}{c|}{ [o] } & \multicolumn{3}{c|}{ [w] } & \multicolumn{2}{c|}{ Orotara } \\
\hline Adina & Kop. & $\%$ & Kop. & $\%$ & Kop. & $\%$ & Kop. & $\%$ \\
\hline Adinek. & 16 & 3,75 & 407 & 95,32 & 4 & 0,94 & 427 & 100 \\
\hline Heldua & 17 & 5,26 & 306 & 94,74 & 0 & 0 & 323 & 100 \\
\hline Gaztea & 38 & 12,14 & 274 & 87,54 & 1 & 0,32 & 313 & 100 \\
\hline
\end{tabular}

[o] hots silabagilea adinekoetan agertzen da gutxien, helduetan eta batez ere gazteetan areagotzeko. [w]-ren kasuan, adibide oso gutxi ditugu ganorazko ondorioak ateratzeko, baina badirudi adinekoek darabiltela gehien, nahiz eta gazteetan adibide bat ere badugun.

Segidan, generoaren eragina da aztertuko duguna. Emazteen eta gizonen arteko aldea estatistikoki ez da esanguratsua $X^{2}$ probaren arabera $\left(X^{2}=(\right.$ a.m.: 2$\left.) 1,521 ; p=0,467\right)$.

Multzokatze-analisiari eta analisi multidimentsionalari erreparatuz, hiztunak lau multzotan sailkatzen dira. Horietarik hirutan, hiztunek gehienik [o] aldaera ez silabagilea badarabilte ere, [o] silabagileak pisu esanguratsua du, batez ere multzo horietariko batean. Bertan ditugu, beste behin ere berritzaile ageri zaigun Gamarte aldeko gizon gaztea eta Ezterenzubiko gizon gaztea ere. [o]-ren erabilera apalduz doa multzo batetik bestera goazen heinean. Hiru multzo horietan ditugu ere, batetik, Arnegi aldeko adineko emaztea, goranzko beste diptongoen kasuan ere, aldaera silabagileen kopuru handi samarra erakutsi duena, eta baita Arnegiko adineko gizona ere. Hiztun hauek salbu, hiru multzo hauetan ditugun hiztun guztiak gazteak edo helduak ditugu, eta Arnegi aldeko hiztunen presentzia ere nabaria da. Hiru multzo horietarik aparte, laugarrenean, beti edo ia beti [o] ahoskatzen duten hiztunak ditugu, denak adinekoak eta helduak. Helduen adin taldea litzateke ia multzo guztietan sakabanatuta ageri zaiguna.

\subsection{0. (t) aldagaia}

(t) aldagaiari erreparatuko diogu ondoren. Euskaraz, orain arte, aldaera herskari, horzkari, apikaria baino ez dugu izan, baina gaur egunean aldaera afrikatu, hobikari, lepokaria ere badugu. Denera, (t) aldagaiari dagozkion 1680 adibide aurkitu ditugu. Horietarik, 1527 (\% 90,89) apikariak izan dira, eta $153(\%$ 9,11) lepokariak. Hergaraiko mutil gaztearen supertoken hau har dezakegu adibidetzat: be[t] $] i$ eta $b e[t] i$. 
Geografiak fenomeno honetan ere badu eraginik, beraz goazen izartzera. 16. taulan datuen kopuruak eta ehunekoak emanen ditugu. Aldea estatistikoki esanguratsua da $\mathrm{X}^{2}$ probaren arabera $\left(\mathrm{X}^{2}=(\right.$ a.m.: 4$\left.) 49,810 ; \mathrm{p}=0,000\right)$.

16. taula: $(t)$ aldagaiaren aldaera apikari eta lepokariaren ahoskatze kopuru eta ehunekoak geografiaren arabera

\begin{tabular}{|l|c|c|c|c|c|c|}
\hline & \multicolumn{2}{|c|}{ Horzkaria } & \multicolumn{2}{c|}{ Hobikaria } & \multicolumn{2}{c|}{ Orotara } \\
\hline Herria & kopurua & $\%$ & kopurua & $\%$ & kopurua & $\%$ \\
\hline Luzaide & 367 & 100 & 0 & 0 & 367 & 100 \\
\hline Arnegi & 302 & 89,09 & 37 & 19,91 & 339 & 100 \\
\hline Ezteren. & 323 & 88,98 & 40 & 11,02 & 363 & 100 \\
\hline Hergarai & 229 & 89,45 & 27 & 10,55 & 256 & 100 \\
\hline Gamarte & 306 & 86,2 & 49 & 13,8 & 355 & 100 \\
\hline
\end{tabular}

16. taula ikus eta, gogorat heldu zaigun lehen gauza da, Luzaiden aldaera lepokaririk ez dagoela. Horrek forogatzen du frantsesetik etorria den fenomeno bat dela, Luzaideko muga pasatu ez duena, han kanpo erdara nagusia gaztelania baita. Bestalde, kasu honetan ere, Gamarte ageri zaigu berritzaileen, bertan baitago aldaera lepokari gehien.

Adinak ( $\mathrm{t}$ ) aldagaiaren gauzatze batean edo bestean duen eragina aztertuko dugu ondoren. 17. taulan datuen kopuruak eta ehunekoak ditugu. Adin taldeen araberako aldea estatistikoki esanguratsua da $X^{2}$ probaren arabera $\left(X^{2}=(\right.$ a.m.: 2) 212,$622 ; p=$ $0,000)$.

17. taula. $(t)$ aldagaiaren aldaera apikari eta lepokariaren ahoskatze kopuru eta ehunekoak adinaren arabera

\begin{tabular}{|l|c|c|c|c|c|c|}
\hline & \multicolumn{2}{|c|}{ Horzkaria } & \multicolumn{2}{c|}{ Hobikaria } & \multicolumn{2}{c|}{ Orotara } \\
\hline Adina & kopurua & $\%$ & kopurua & $\%$ & kopurua & $\%$ \\
\hline Adinek. & 579 & 99,83 & 1 & 0,17 & 580 & 100 \\
\hline Helduak & 586 & 94,82 & 32 & 5,18 & 618 & 100 \\
\hline Gazteak & 362 & 75,1 & 120 & 24,9 & 482 & 100 \\
\hline
\end{tabular}

Adinekoetan ahoskune lepokariaren adibide bakarra dugu, ia anekdotikotzat har genezakeena. Ahoskune lepokariaren kontuan hartzeko moduko adibide kopurua helduetan ageri zaigu, eta nabarmen hazten da gazteetarat jauzi eginez geroz.

Generoak ere badu eraginik fenomeno honetan. 18. taulan ahoskera bakoitzaren datu kopuruak eta ehunekoak emanen ditugu. Bertan ikus daitezkeen aldeak estatistikoki esanguratsuak dira $\mathrm{X}^{2}$ probaren arabera $\left(\mathrm{X}^{2}=(\mathrm{a} . \mathrm{m} .:\right.$ 1) 28,$894 ; \mathrm{p}=0,000)$. 
18. taula. ( $t$ ) aldagaiaren aldaera apikari eta lepokariaren ahoskatze kopuru eta ehunekoak generoaren arabera

\begin{tabular}{|l|c|c|c|c|c|c|} 
& \multicolumn{2}{|c|}{ Horzkaria } & \multicolumn{2}{c|}{ Hobikaria } & \multicolumn{2}{c|}{ Orotara } \\
\hline Generoa & kopurua & $\%$ & kopurua & $\%$ & kopurua & $\%$ \\
\hline Emazte. & 633 & 86,59 & 98 & 13,41 & 731 & 100 \\
\hline Gizonez. & 894 & 94,2 & 55 & 5,8 & 949 & 100 \\
\hline
\end{tabular}

Bertan ikus genezakeenez, kasu honetan, beste batzuetan ez bezala, emakumezkoak dira berritzaile direnak, eurak baitarabilte aldaera lepokaria gehienik.

Multzokatze-analisia eta analisi multidimentsionala ikusita, Gamarteko neska gaztea erabat bakarrik ageri zaigu, ia beti baitarabil aldaera lepokaria. Maila anitzez apalagoan darabilte Arnegi aldeko eta Hergarai aldeko gizon gazteek, eta Ezterenzubiko neska gazteak. Eta maila apalagoan oraindik ere, Arnegi aldeko emazte gazteak, eta Gamarte aldeko eta Ezterenzubiko gizon gazteek. Gazte hauekin batera, multzo honetan heldu batzu ageri dira lehenengoz, denak emazteak: Hergaraikoa, Ezterenzubikoa eta Arnegikoa. Hauengandik aparte, beste multzo batean, aldaera apikaria da erabat nagusi. Azpimarratzekoa da, luzaidar guztiak multzo honetan ageri direla, eta beraz, kasu honetan, dardarkarienean bezalaxe, muga politikoa barrera izan dela berrikuntza hau hedatzeko unean.

\subsection{1. (d) aldagaia}

(t) aldagaiaren kasuan bezalaxe, (d) aldagaiaren kasuan ere, hots herskari, horzkari, apikaria izan da nagusi oraintsu arte. Gure garaiotan ordea, frantsesaren eraginez, segurrenik ere, hots afrikatu, hobikari, lepokaria hedatzen doa. Gure corpusean 1595 datu bildu ditugu denera, 1540 (\% 96,55) aldaera apikari eta $55(\%$ 3,45) aldaera lepokari. Arnegi aldeko adineko emazteak hots apikariaren adibide hau dakar: al[d] $] i z$. Gamarteko neska gazteak berriz, hots lepokariaren beste hau: men[d]iak.

Lehenik eta behin, geografiak fenomeno honetan duen eragina izartuko dugu. Datuen kopurua eta ehunekoak 19. taulan daude. Aldeak estatistikoki esanguratsuak dira $\mathrm{X}^{2}$ probaren arabera $\left(\mathrm{X}^{2}=(\mathrm{a} . \mathrm{m} .: 4) 74,444 ; \mathrm{p}=0,000\right)$.

19. taula. (d) aldagaiaren aldaera apikari eta lepokariaren ahoskatze kopuru eta ehunekoak geografiaren arabera

\begin{tabular}{|l|c|c|c|c|c|c|} 
& \multicolumn{2}{|c|}{ Horzkaria } & \multicolumn{2}{c|}{ Hobikaria } & \multicolumn{2}{c|}{ Orotara } \\
\hline Herria & kopurua & $\%$ & kopurua & $\%$ & kopurua & $\%$ \\
\hline Luzaide & 372 & 100 & 0 & 0 & 372 & 100 \\
\hline Arnegi & 272 & 97,14 & 8 & 2,86 & 280 & 100 \\
\hline Ezteren. & 348 & 97,21 & 10 & 2,79 & 358 & 100 \\
\hline Hergarai & 265 & 99,25 & 2 & 0,75 & 267 & 100 \\
\hline Gamarte & 283 & 88,99 & 35 & 11,01 & 318 & 100 \\
\hline
\end{tabular}


(t)-ren kasuan bezalaxe, (d)-renean ere, aldaera lepokaria frantsesaren eragina dela baieztatzen duela erranen genuke Luzaiden ahoskune hau duen hotsik ez izateak, gaztelaniaz ez baitago. Beste behin, Gamarte aldea ageri zaigu hizkuntza-ezaugarri honi dagokionez berritzaileen.

Adinaren eraginari erreparatuko diogu jarraian, datuen kopuruak eta ehunekoak 20. taulan erakutsiz. Aldeak kasu honetan ere, estatistikoki esanguratsuak dira $\mathrm{X}^{2}$ probaren arabera $\left(\mathrm{X}^{2}=(\mathrm{a} . \mathrm{m} .: 2) 104,786 ; \mathrm{p}=0,000\right)$.

20. taula. (d) aldagaiaren aldaera apikari eta lepokariaren ahoskatze kopuru eta ehunekoak adinaren arabera

\begin{tabular}{|l|c|c|c|c|c|c|}
\hline & \multicolumn{2}{|c|}{ Horzkaria } & \multicolumn{2}{c|}{ Hobikaria } & \multicolumn{2}{c|}{ Orotara } \\
\hline Adina & kopurua & $\%$ & kopurua & $\%$ & kopurua & $\%$ \\
\hline Adinek. & 577 & 99,83 & 1 & 0,17 & 578 & 100 \\
\hline Helduak & 512 & 99,61 & 2 & 0,39 & 514 & 100 \\
\hline Gazteak & 451 & 89,66 & 52 & 10,34 & 503 & 100 \\
\hline
\end{tabular}

(t)-ren kasuan ez bezala, adinekoez gain, helduen kasuan ere biziki apala da aldaera lepokariaren ehunekoa. Gazteetan, ordea, anitz handitzen dela dakusagu.

Azkenik, generoaren eraginari erreparatuko diogu. Datuen kopuruak eta ehunekoak 21. taulan ditugu islatuta. Aldeak estatistikoki esanguratsuak dira $\mathrm{X}^{2}$ probaren arabera $\left(\mathrm{X}^{2}=(\right.$ a.m.: 1) 12,396; $\mathrm{p}=0,000)$.

21. taula. (d) aldagaiaren aldaera apikari eta lepokariaren ahoskatze kopuru eta ehunekoak generoaren arabera

\begin{tabular}{|l|c|c|c|c|c|c|}
\hline & \multicolumn{2}{|c|}{ Horzkaria } & \multicolumn{2}{c|}{ Hobikaria } & \multicolumn{2}{c|}{ Orotara } \\
\hline Generoa & kopurua & $\%$ & kopurua & $\%$ & kopurua & $\%$ \\
\hline Emazte. & 748 & 94,92 & 40 & 5,08 & 788 & 100 \\
\hline Gizonez. & 792 & 98,14 & 15 & 1,86 & 807 & 100 \\
\hline
\end{tabular}

(t)-ren kasuan bezalaxe, fenomeno honi dagokionez ere, emazteak ageri zaizkigu berritzaileen.

Multzokatze-analisiari eta analisi multidimentsionalari dagokienez, (t)-ren kasuan bezalaxe, hemen ere Gamarteko neska gazteak, erabat aparte, multzo beregaina osatzen du, aldaera lepokaria besteek baino kopuru anitzez ere handiagoan baitarabil. Berriz ere elkarrekin doaz Ezterenzubiko neska gaztea eta Arnegiko gizon gaztea, eta beraiekin batera dugu Gamarteko gizon gaztea. Beste guztiek batere edo oso kopuru txikietan darabilte aldaera lepokaria. 


\subsection{Informatzaileen sailkapen orokorra}

Azkenik, hizkuntza-ezaugarri guztiak aztertu ondoren, datu guztiak kontuan hartuta, informatzaileen sailkapen orokorra eginen dugu multzokatze-analisiaren bidez 1 . irudian eta analisi multidimentsionalaren bidez 2.ean.

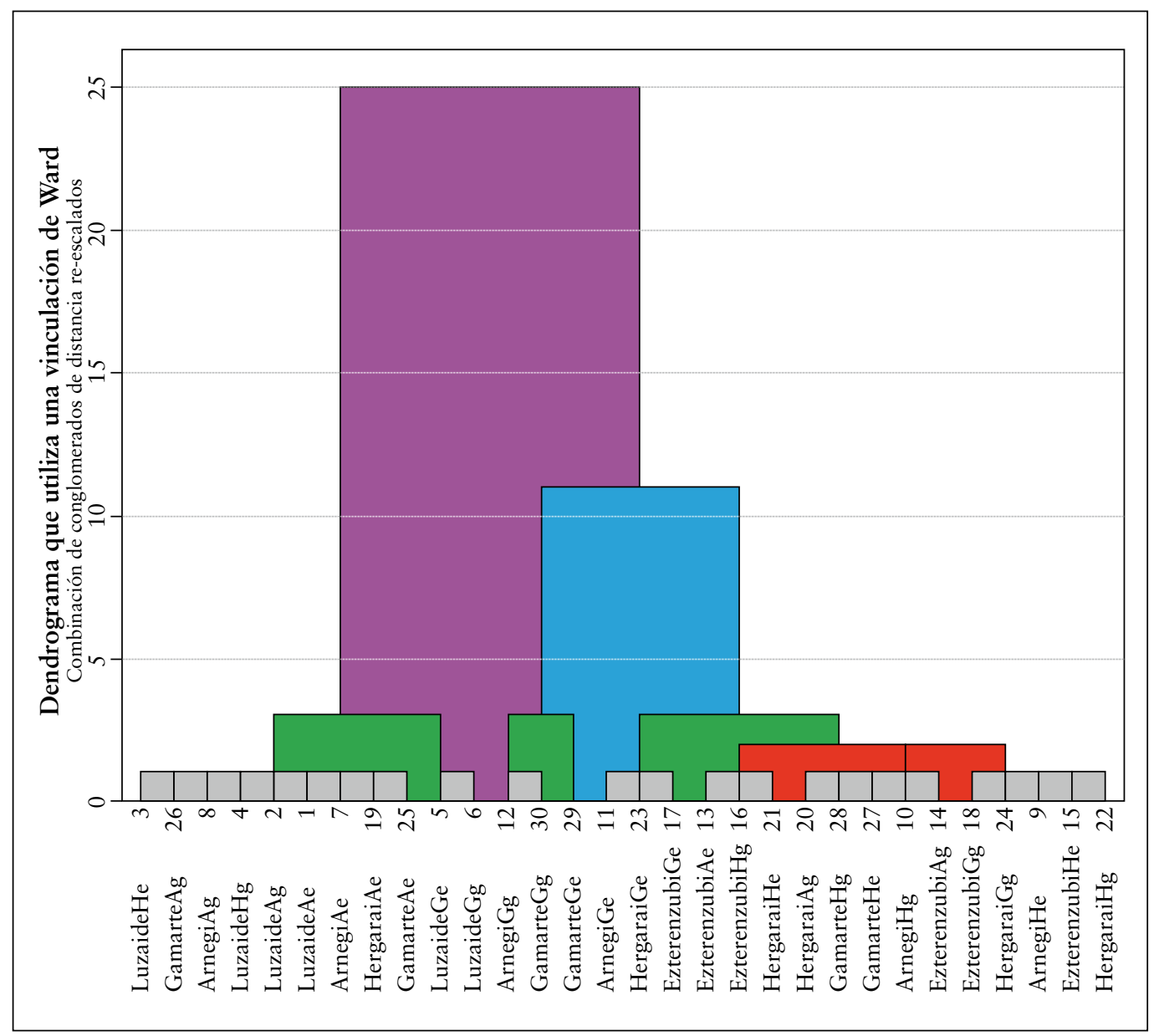

1. irudia. Informatzaileen sailkapen orokorra multzokatze-analisiaren bidez.

1. irudiko dendogramari erreparatuta ${ }^{1}$, geografiari dagokionez, Luzaide aparte ageri da beste guztiengandik Garaziko gainerako herrietako zaharrekin batera. Adinari dagokionez ere, bereizketa argia ageri da. Adineko kontserbatzaileenak ezkerreko

1 1. eta 2. irudietako laburdurei dagokienez, $A$ hizkiaren bidez adineko erran nahi dugu, $H$-ren bidez, beldu eta $G$ handiaren bidez, gazte. $g$ txikiaren bidez berriz, gizon, eta $e$-ren bidez emakume. Horrela bada, adibidez, GamarteAe-k Gamarte aldeko adineko emakumea erran nahi du. 
multzoan doaz luzaidarrekin batean, eta gainerakoek eskuineko multzoa osatzen dute. Azken honetan, mailarik oinarrizkoeneko hiru multzoetan ez da adinaren araberako bereizketa garbirik ageri, baina mailaz igotzen goazen ber, berritzaileen diren gazteak gehitzen dira, besteengandik aparteago daudela adieraziz. Generoaren arabera, berriz, neke da multzo garbirik definitzea.

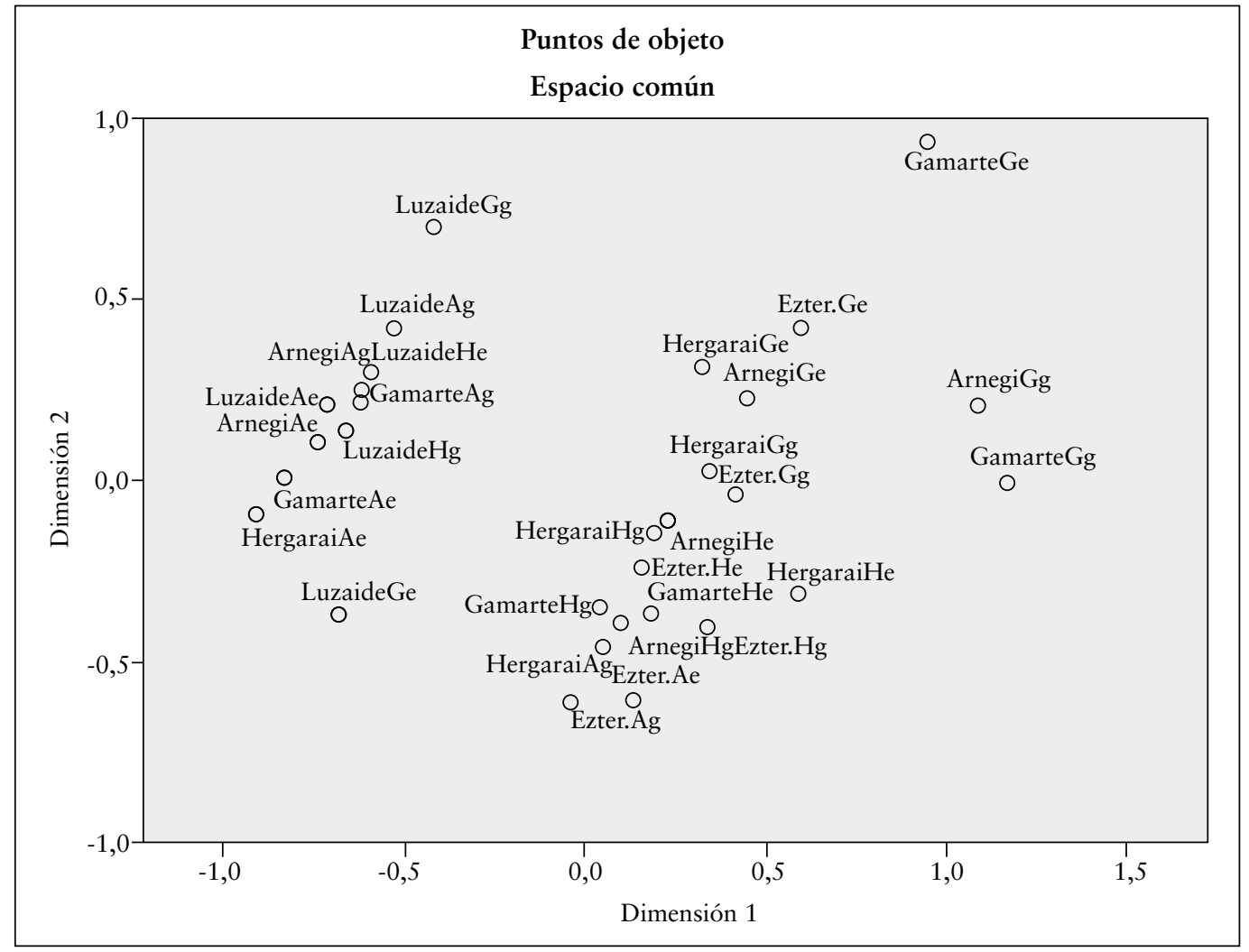

2. irudia. Informatzaileen sailkapen orokorra analisi multidimentsionalaren bidez.

2. irudian ere, geografiaren araberako bereizketa argia ageri da, luzaidar guztiek gainerako herrietako adineko kontserbatzaileenekin batera multzo beregaina osatzen baitute. Adinari dagokionez ere, ezkerreko multzoan, gainerako herrietako adineko kontserbatzaileenak luzaidarrekin batera ditugu. Multzo horretako gazteak ere bereiz samar ageri dira besteengandik. Eskuinekoan ere bereizketa dago, adineko berritzaileenak beheko aldean baititugu, helduak erdian, eta gazteak goian, batzuk gainera, besteengandik nahiko urruti. Generoaren araberako bereizketarik ez da ageri.

\section{ONDORIOAK}

Datuen azterketa burutu ondoren, orain ondorioak ateratzea dagokigu. Lanaren hasieran proposatu ditugun hipotesiak betetzen diren edo ez ikusiko dugu. 
Hauek izan dira lan honetan aztertu ditugun menpeko aldagaiak: hasperena (hitz hasieran, bokal artean eta herskari hasperendunak), dardarkariak, (1) araua $([\mathrm{u}] \rightarrow$ $<\mathrm{i}>$ I_[a, e]), goranzko diptongoak ((2), (3), (4) eta (5) arauak ([i] $\rightarrow<\mathrm{j}>$ I_[a, e, o, u]); [u] $\rightarrow<\mathrm{w}>$ I_[a, e, i, o]; [e] $\rightarrow<\mathrm{i}$, e, j $>$ I_[a] eta [o] $\rightarrow<\mathrm{o}, \mathrm{u}, \mathrm{w}>$ I_[a])), eta (t) eta (d) aldagaiak.

Menpeko aldagai hauek berriz, honako aldagai askeen arabera aztertu ditugu: geografia, adina eta generoa.

Gure hipotesi orokorra Garaziko euskara abiada bizian aldatzen dabilela da, eta hipotesi zehatzak berriz, aldaketa hori geografiaren, adinaren eta generoaren arabera gertatzen dela.

Geografiarekin hasita, aldagai hau, aztertu ditugun hamaika hizkuntza-ezaugarrietatik, zortzitan agertu zaigu estatistikoki esanguratsu: hitz hasierako hasperenaren kasuan, herskari hasperendunen kasuan, dardarkarietan, (1), (4) eta (5) arauetan, eta azkenik $(t)$ eta $(d)$ aldagaien kasuan.

Goazen lehenik eta behin, Luzaidera begira jartzera. Gure hasierako hipotesia zen herri hau gainerakoetarik aparte gelditzen ari dela muga politikoak hala eraginda. Hasteko, geografia adierazgarri agertu ez den kasuetan hala izan ez dela erran behar dugu, hots, bokal arteko hasperenaren kasuan, eta (2) eta (3) arauen kasuan. Geografia esanguratsu gertatu den ezaugarrien kasuan berriz, espero baino kasu gutxiagotan gelditu da Luzaide gainerako herrietarik aparte, baina dardarkarien kasuan eta $(t)$ eta (d) aldagaien kasuan muga politikoaren eragina nabarmena izan da, frantsesaren eraginez hedatu diren dardarkari ubularraren eta $(t)$ eta $(d)$ aldagaien aldaera lepokariaren inolako adibiderik ez baitugu ediren Luzaiden. Luzaide aparte gelditu ez den gainerako ezaugarrietan, hots (1), (4) eta (5) bilakabideen kasuan, euskara batuaren edota euskara idatziaren eragina aipa genezake, mugaren bi alderdietan antzekoa izan daitekeena. Kasu hauetan guztietan, eta hasperenaren kasuan ere, Luzaiden gertatu den aldaketa eta beste herrietan gertatu dena abiadura bertsuan joan direla erran genezake.

Hiru hizkuntza-ezaugarri horietan Luzaide Garaziko gainerako herrietarik aparte gelditzearen zergatiak giza harremanetan atzematen ahal ditugu. Adinekoek beti izan dute Garaziko beste gainerako herrietarat joateko usaia, bai bestetarako, baita eguneroko beharretarako ere. Mugaren eraginarengatik, ordea, helduetan etena gertatu da ibarrarekiko harremanetan, eta Ibañetaz bestalde joateko usaia hartu dute. Gazteak, gaur egun oraindik ere, Garralda eta Iruñerat joaten dira gehienbat ikastera, baina bestetara beti eta gehiago joaten dira Garaziko eta Iparraldeko herrietara. Etorkizunean, joera berri horrek eraginik duen ikusi beharko da.

Frantsesaren eraginez hedatu diren berrikuntzetan, Luzaide genuke kontserbatzaileen. Luzaidetik landa edota frantsesaren eraginik izan ez duten beste ezaugarriei dagokienez, eta joera argirik ageri ez bada ere, Gamarte litzateke kontserbatzaileen.

Berritzaileen ageri den eremu geografikoari dagokionez berriz, kasu honetan ere ez dugu argi eta garbi berritzaile ageri den eremurik, baina bat izatekotan Gamarte aldea 
dugu. Badirudi, beraz, adinekoak, eta gizon heldua ere, kontserbatzaileak direla, baina gazteak berritzaile ageri direla. Dena dela, hau joera orokorra den edo elkarrizketatu ditugun hiztunen joera den jakiteko, gure informatzaileen lagina handitzeko beharra ikusten dugu.

Adinari bagagozkio, adierazgarria da benetan, hamaika ezaugarritatik, bederatzitan izan dela adina estatistikoki esanguratsu. Herskari hasperendunak eta (2) araua dira adinaren araberako alde esanguratsurik ez dutenak. Beste kasu ia guztietan, espero genuen bezala, adinekoak izan dira kontserbatzaileenak eta gazteak berriz, berritzaileen. (4) arauaren kasuan, [j]-ren aldeko joera indartuz doala dirudi helduengan, aitzinatzen ari den bilakabidea dela, hots, baina egoera erabat uzkailtzen da gazteetarat jauzi eginez geroz.

Alde berdina ote dago adinekoetarik helduetarat edo helduetarik gazteetarat? Adinekoetarik helduetara alde handiagoa dago bokal arteko hasperenaren kasuan, dardarkarien kasuan, eta (3) arauaren kasuan. Alta, helduen eta gazteen arteko aldea handiagoa izan da (1), (4) eta (5) arauen kasuan, baita (t) eta (d) aldagaien kasuan ere. Hitz hasierako hasperenari dagokionez, hiru belaunaldien arteko aldeak berdintsuak dira.

Gazteek euskararen eredu estandar eta idatziarekin izan duten harremanak, (1), (4) eta (5) arauetan, alderik nabarmenena helduen eta gazteen artekoa izatea azalduko luke, ikastolan ikasi baitute denek, eta beraz, euskaraz jaso baitute hezkuntza sistema osoa. Bestalde, batez ere, gazteak izan dira gizarte frantsestuan haziak izan direnak, eta horrek azal lezake gure iritziz $(t)$ eta $(d)$ aldagaien aldaera lepokariak adin talde honetan hain nabarmen agertzea. Faktore horietaz landa, levelling edo dialektoen arteko berdintze fenomenoa ere aipatu beharra dago. Gaur egun, ikastoletan dabiltzanak dira euskara jakin eta erabiltzen duten gazte ia bakarrak. Denek lizeo bakar batean ikasten dute, Etxepare lizeoan, Baionan, eta lizeo elebidun publikora pasatzea erabakitzen dutenek ere, Etxeparen ibilitakoekin dituzte harremanak. Horrez gain, Ipar Euskal Herri ruralak galdu du garai batean zuen garrantzia eta nortasuna. Gaur egun, Baiona eta kostaldera begira dago ia Iparralde osoa, han daude gaur egungo bizi modernoan beharrezkoak diren zerbitzuetako asko, eta joan-etorriak etengabekoak dira kostaldearen eta Garaziren artean. Gizartea Garazi mailan mugitzetik Iparralde mailan mugitzera igaro da beraz, kostaldea ardatz izanik, eta horrek dialektoen arteko berdintzea edota levelling-a eragin du.

Dardarkarietan, adinekoen eta helduen artean gertatu da alderik handiena, funtsean helduek adinekoek baino eskola gehiago egin baitute. Aldaera apikaria, edota Hergaraiko adineko emazteak zioskun bezala, "erre itsusi horiek», frantses txartzat ikusiak izan dira, eta hauek desagerrarazteko eskola funtsezko tresna izan dela erranen genuke.

Generoari dagokionez azkenik, hamaika hizkuntza-ezaugarritatik lautan izan da aldagai hau estatistikoki esanguratsu: hitz hasierako hasperenean (bokal artekoan esanguratsu izan ez bada ere, emazteak izan dira kontserbatzaileago izan direnak), dardarkarien kasuan, eta (t) eta (d) aldagaien kasuan, hain zuzen ere. Berau izan da beraz, hiru aldagaietatik eragin txikiena izan duena. Aipagarria dena da lehen bi ezaugarriotan 
emazteak izan direla kontserbatzaileen, eta azken bietan berriz berritzaileen. Kontuan har dezagun, hasperenak eta dardarkari apikariak ahoskatzen dituztenak adinekoak direla batez ere, eta $(\mathrm{t})$ eta $(\mathrm{d})$ aldagaien aldaera lepokariak ahoskatzen dituztenak berriz, gazteak. Beraz, ondoriozta genezake, Caminori (2009c, 299-300. orr.) jarraituz, emazteak, adinekoak behintzat, kontserbatzaileago direla gurean, gizonak ez bezala, ferietarat eta abar, ez baitute mugitzeko aukera handirik izan, eta etxean egotera behartuak izan baitira. Gazteetan, ordea, hirietako emazteen joera ageri da, berritzaileagoak direla, hain zuzen ere. Emazteek garai batean baino askatasun gehiago dute gaur egunean eta mugikortasuna ere erdietsi dute. Gaur egungo gizarte modernoak, ordea, Trudgill-i (1986 [1983], 400. orr.) jarraituz, besteek erranen dutenari begira egotera eta gizartean egin ahala posizio gora atxiki nahi izatera behartzen ditu, oraindik ere gizonezkoak baino maila apalagoan baitaude, eta hori, besteak beste, hizkuntzaren bidez egiten dute. Hargatik, «modan» dauden ( $\mathrm{t}$ ) eta (d)-ren aldaera lepokarien aldeko hautua egiten dute. Hori emazte helduen kasuan ongi ageri da, emazteak baitira $(t)$ eta (d)-ren aldaera lepokariak erabiltzen bakarrak. Gizon helduek berriz, ez dituzte batere erabiltzen, salbuespen bakarren bat gorabehera.

Aurrera begirako asmoei dagokienez, informatzaileen kopurua handitu beharra ikusten dugu, emaitzen fidagarritasuna handitzeko asmoz. Horrez gain, hizkuntz ezaugarri gehiago aztertu beharra ere ikusten dugu, fonetiko-fonologikoak baina baita morfologiari dagozkionak ere. Horrela, ibarreko euskararen ikuspegi osoagoa izango baikenuke. Azkenik, orain arte aztertu ditugun aldagai sozialei beste bat gehitzea ere premiazko ikusten dugu: heziketa-eredua, hain zuzen ere. Hots, ikastolan ikasi duten gazteez gain, eskola publiko frantses edo elebidunean ibili diren gazteen mintzoa ere aztertu nahi genuke, bi taldeen artean desberdintasun nabarmenak daudelako ustea baitugu.

\section{ERREFERENTZIAK}

Ariztimuño, B. (2010). Tolosako eta Ataungo hizkerak. Hizkuntz bariazioa eta konbergentzia-joerak. Uztaro, 72, 79-96.

Aurnague, J. \& Duguine, M. (2004). Euskaldun orok altxa burua: Enquête sociolinguistiques en Garazi 1982, 2002. Lankidetzan, 33, 41-151.

Aurrekoetxea, G. (2004). Estandar eta dialektoen arteko bateratze-joerak (ikuspuntu teorikotik begirada bat). Uztaro, 50, 45-57.

Aurrekoetxea, G. (2006). Hizkuntza estandarraren eta dialektoen arteko bateratze joerak. ASJU, 40(1-2), 133-160.

Aurrekoetxea, G. (2008). Bariazio soziolinguistikoa Dimako euskaran. Euskalingua, $12,17-26$.

Aurrekoetxea, G. \& Ormaetxea, J. L. (2006). Euskararen Atlas Sozio-geolinguistikoa ikerketa-proiektua. Euskalingua, 9, 157-163.

Aurrekoetxea, G. \& Videgain, X. (2004). Haur prodigoaren parabola Ipar Euskal Herriko 150 bertsiotan. Bilbo: Euskal Herriko Unibertsitatea. (ASJU-ren Gehigarriak, 49).

Aurrekoetxea, G., Videgain, C. \& Iglesias, A. (2004). «Bourciez» bildumako euskal atlasa (BBEA): 1. Lexikoa. ASJU, 38(2). 
Aurrekoetxea, G., Videgain C. \& Iglesias, A. (2005). «Bourciez» bildumako euskal atlasa (BBEA): 2. Gramatika. ASJU, 39(1).

Boersma, P. \& Weenink, D. (2016). Praat: doing phonetics by computer, Version 5.1. [computer program]. Sarean eskuragarri: <http://www.praat.org >

Bonaparte, L. L. (1881). Observaciones acerca del vascuence de Valcarlos. Revista Euskara, 4, 161-66.

Borrego-Nieto, J. (1981). Sociolingüística rural. Investigación en Villadepera de Sayago. Salamanca: Universidad de Salamanca.

Camino, I. (1987 [1983]). Nafarrera Beherea. In Txillardegi \& G. Aurrekoetxea (arg.), Euskal Dialektologiaren Hastapenak (313-426. orr.). Bilbo: UEU.

Camino, I. (2004). Nafarroa Behereko Euskara. FLV, 97, 445-486.

Camino, I. (2008). Nafarroa Behereko euskara zaharra. ASJU, 42(1), 101-170.

Camino, I. (2009a). Hizkuntza-aldakortasunari Amiküzetik so. Lapurdum, 13, 61-80.

Camino, I. (2009b). Mugako hiztun eta aldaerak ipar-mendebaleko Zuberoan. FLV, $111,153-218$.

Camino, I. (2009c). Dialektologiatik euskalkietara tradizioan gaindi. Donostia: Elkar.

Camino, I. (2015a). Oztibarreko mintzoaz eta haren lexikoaz. FLV, 119, 5-60.

Camino, I. (2015b). Amiküzeko heskuararen hezurdura lektala. In I. Epelde (arg.), Euskal hizkera eta dialektoak gaur egun (27-79. orr.). Baiona: UBM \& UPPA.

Camino, I. (2016). Amiküze eskualdeko heskuara. Bilbo: Euskaltzaindia.

Eckert, P. (1989). The whole woman: sex and gender differences in variation. Language Variation and Change, 1, 245-267.

Eckert, P. (1997). Age as sociolinguistic variable. In F. Coulmas (arg.), The handbook of sociolinguistics (151-167. orr.). Oxford: Blackwell.

Ensunza, A. (2012). Gernika-Lumoko euskararen aldakortasuna: aldagai fonetiko zenbait. ASJU, 46(2), 177-244.

Ensunza, A. (2014). Gernika-Lumoko euskararen aldakortasuna: aldagai fonetiko zenbait. BAT Soziolinguistika aldizkaria, 90, 123-149.

Ensunza, A. (2015). Busturialdeko euskararen aldakortasuna denboran eta espazioan. UPV/EHUko doktorego tesia.

Etxebarria, M. (1985). Sociolingüística urbana: el habla de Bilbao. Salamanca: Universidad de Salamanca.

Etxebarria, M. (2000). Variación sociolingüística en una comunidad bilingüe. Bilbo: Euskal Herriko Unibertsitateko argitalpen zerbitzua, UPV/EHU.

Euskaltzaindia. (2008-16). Euskararen herri hizkeren atlasa (EHHA), 8 liburuki. Bilbo: Euskaltzaindia.

Gaminde, I. (2010). Bilboko gazte euskaldunen ezaugarri linguistikoez. In K. Altonaga \& Mendebalde kultur elkartea (arg.), Bilbon mundua ikusi. XIV. Jardunaldiak (35-59. orr.). Bilbo: Mendebalde Euskal Kultur Alkartea.

Gaminde, I. \& Romero, A. (2011). Generoa eta adina Bermeoko berbaldiaren fonemen eta hotsen frekuentzian. FLV, 113, 115-138.

Gaminde, I., Romero, A. \& Legarra, H. (2012). Gramatika eta hizkuntza bariazioa Bermeon. Bermeo: Bermeoko Udala.

Gaminde, I., Etxebarria, A., Eguskiza, N., Romero, A. \& Iglesias, A. (2017). Dardarkari anizkunaren aldakortasunaz. FLV, 123, 29-64. 
Gandarias, L. (2012). Azentu bariazio soziogeolinguistikorako lehen hurbilpena Kortezubin, Lekarotzen eta Tolosan (HIZNET graduondoko sakontze-egitasmoa).

Garazi-Baigorri Herri Elkargoa (2017). Garazi-Baigorri herri elkargoa. Sarean eskuragarri: <http://www.garazibaigorri.com/eu/ekonomia.html>

Haddican, B. (2003). Dialect Contact in a Southern Basque Town. Language and Variation and Change, 15(1), 1-35.

Haddican, W. F. (2005). Aspects of language variation and change in contemporary Basque (doktore-tesia). New York: New York University, Graduate School of Arts and Science, GSAS.

Haddican, B. (2007). Suburbanization and language change in Basque. Language in Society, 36, 677-706.

Hualde, J. I. (1998 [1991]). Basque phonology. New York: Routledge.

Hualde, J. I. (2003). Segmental Phonology. In J. I. Hualde \& J. Ortiz de Urbina (arg.), A grammar of Basque (15-65. orr.). Berlin: Mouton de Gruyter.

Irizar, P. (1981). Contribución a la dialectología de la lengua vasca (I). Donostia: Gipuzkoako Aurrezki Kutxa Probintziala.

Jauregi, O. \& Epelde, I. (2013). Hasperenaren galera Iparraldeko euskaran. In R. Gómez, J. Gorrochategui, J. A. Lakarra \& C. Mounole, (arg.), Koldo Mitxelena Katedraren III. Biltzarra - III Congreso de la Cátedra Luis Michelena - 3rd Conference of the Luis Michelena Chair (245-262. orr.). VitoriaGasteiz: UPV/EHU.

Kamino P. \& Salaberri P. (2001a). Hitz eratorriak Luzaideko hizkeran. FLV, 86, 67-86.

Kamino P. \& Salaberri P. (2001b). Aditz trinkoen orainaldiko formak Luzaideko hizkeran. FLV, 87, 193-202.

Kamino P. \& Salaberri P. (2004). Nafarroa Behereko hiru eskutitz. FLV, 95, 89-113.

Kamino P. \& Salaberri P. (2006). Luzaide eta Ondarrolako hiru gutun. FLV, 38, 95-108.

Kamino P. \& Salaberri P. (2007). Luzaideko euskararen hiztegia. Iruñea \& Bilbo: Nafarroako Gobernua \& Euskaltzaindia.

Labov, W. (1963) The social motivation of a sound change. Word, 19, 273-309.

Labov, W. (1966). The linguistic variable as a structural unit. Washington linguistic review, 3, 4-22.

Labov, W. (1969). Contraction, deletion, and inherent variability of the English copula. Language, 45, 715-762.

Labov, W. (1972). Sociolinguistic Patterns. Filadelfia: University of Pensylvania press.

Labov, W. (2001). Principles of Linguistic Change: Volume 2: Social Factors. Malden \& Oxford: Blackwell.

Ladefoged, P. \& Maddieson I. (1996). The Sounds of the World's Languages. Oxford \& Cambridge: Blackwell.

Lujanbio, O. (2012). Hizkuntza-aldakortasuna Goizuetako euskaran. Uztaro, 80, 7797.

Lujanbio, O. (2014). Hizkuntza-aldakortasuna Goizuetako euskaran: emaitza gehiago. In I. Aduriz \& R. Urizar (arg.). Euskal bizkuntzalarien egungo zenbait ikerlerro (231-255. orr.). Eibar: UEU.

Lujanbio, O. (2016). Hizkuntza-aldakortasuna euskaran. Nafarroa ipar-mendebaldeko bi udalerritan egindako azterketa. UPV/EHUko doktore-tesi argitaragabea. 
McConnell-Ginet, S. (1988). Language and gender. In F. Newmeyer (arg.), Linguistics: The Cambridge survey, IV. Language: The sociocultural context (75-99. orr.). Cambridge: Cambridge University Press.

Mitxelena, K. (1990) [1977]. Fonética Histórica Vasca. Donostia: Gipuzkoako Foru aldundia.

Milroy, L. (1980). Language and social networks. London \& Baltimore: Basil Blackwell \& University Park Press.

Ormaetxea, J. L. (2008). Otxandioko hizkera: adinaren araberako bariazioa. FLV, 108, 249-262.

Oyharçabal, B. (2009). Norantz proiektua datu-basea. Sarean eskuragarri: <www.norantz.org>

Perez Landa, E. (2006). Bokal-elkarketak beratarren hizkeran. Uztaro, 57, 49-64.

Russell, A. (2010). Realisation variable des occlusives en français louisianais: l'affrication et l'aspiration a la Ville Platte. In F. Neveu, V. Muni Toke, J. Durand, T. Klingler, L. Mondada \& S. Prevost (arg.), Congres Mondial de Linguistique Francaise - CMLF (1357-1368. orr.). Paris: Institut de Linguistique Française.

Salaberri, P. (2000). Luzaideko euskara, Mezkirizkoaren eta Aezkoakoaren argitan. In K. Zuazo (arg.), Dialektologia gaiak (223-259. orr.). Gasteiz: Arabako Foru Aldundia.

Santazilia, E. (2009). Luzaideko hizkuntz bariazioa. FLV, 41, 219-248.

Silva-Corvalán, C. (1988). Sociolingüística: teoría y análisis. Madril: Alhambra.

Soziolinguistika Klusterra (2017). Euskararen datu soziolinguistikoen biltegia. Sarean eskuragarri: <http://www.soziolinguistika.eus/edb/index.php?lurraldea=h644>

Stevens, K.N. (1998). Acoustic Phonetics. Cambridge \& London: The MIT Press.

Tagliamonte, S. (2012). Variationist sociolinguistics: change, observation, interpretation. Malden, MA: Wiley-Blackwell.

Trudgill, P. (1986 [1983]). Social identity and linguistic sex differentiation. In H. B. Allen \& M. D. Linn (arg.), Dialect and language variation (395-402. orr.). Orlando, Florida: Academic Press, INC.

Txillardegi (1980). Euskal Fonologia. Donostia: Ediciones Vascas.

Unamuno, L. (2010). Adinaren araberako bariazioa Gizaburuagako hizkeran. Euskalingua, 16, 41-48.

Zarraga, A., Coyos, J. B., Hernández, J. M., Joly, L. Larrea, I., Martínez, L. V., Uranga, B. \& Bilbao, P. (2010). Soziolinguistika eskuliburua. Gasteiz: Eusko Jaurlaritza \& Soziolinguistika klusterra. 